\title{
Medine Site Devletinin Sosyo-Politik Altyapısı
}

\author{
İlyas AKYÜZOĞLU *
}

\section{Özet}

Devlet denilen siyasal yapının nasıl ve ne zaman ortaya çıktığı tam olarak bilinememektedir. Fakat bilinen bir gerçektir ki devlet diye adlandırdığımız bu tüzel kişiliğin işlevsel olabilmesi için mutlaka birileri tarafindan organize edilmesi ve yönetilmesi gerekmektedir. Bu yönetim ihtiyacı devlet yapılanmalarının en basit halini meydana getirmiş ve zamanla evrilerek günümüzdeki modern haline kavuşmuştur.

Biz bu makalemizde, İslam'ın Medine döneminde hicret sonrası ortaya ç1kan siyasi ve sosyal yapılanmayı ortaya koymaya çalıştık. Çünkü İslam dünyasında Hz. Muhammed'in öncülügünde bir devlet yapılanması ortaya çıkmıştı. Peygamber olarak toplum lideri olan Hz. Muhammed, devletin teşekkül etmesiyle birlikte de siyasal liderlik vasfını kazanmış ve vefatına kadar da devlet başkanlığ1 görevini yürütmüştür.

Anahtar Kelimeler: Hz. Muhammed, Site Devleti, İslam Tarihi, Medine Dönemi.

\section{Medina The State of Site and Its Socio-Political Substructure}

\section{Abstract}

How and when did the political structure which so-called state arise is unknown. But what the well-known fact is that this incorporated body which we called state must be organized and managed by some people for being a functional means. This management needs has created simplest version of the state structure and evolved over time into a form of modern today.

In this article we have tried to analyze political and social restructuring in Yrd.Doç.Dr., Yalova Üniversitesi İslami İlimler Fakültesi Öğretim Üyesi.

tel: 5335684470 e-posta: ilyasakyuzoglu@gmail.com

YIL: 6 SAYI: 11 
Medina period it emerged after migration. Because in the Islamic world, there was a state structure created by the leadership of Prophet Mohammad. As a key community leader, Prophet Mohammad acquired political leadership when the state constituted and he ruled the state until he passed away.

Keywords: Prophet Mohammad, Site State, Islamic History, Medina Period.

\section{Giriş}

Devlet kelimesi Arapça “d-v-l” kökünden gelir; “değişmek; nöbetleşe birbiri ardınca gelmek, dolaşmak; üstün gelmek, zafer kazanmak” gibi anlamları vardır. ${ }^{1}$ Batı dillerinde günümüz modern anlamıyla "devlet", "state" (İng.), "etat" (Fr.), "staat" (Alm.), kelimeleri ile ifade edilmektedir. Bu kelimelerin hepsinin kaynağı Latince' de "ayakta durmak, hal ve durum" anlamlarına gelen "stare" kökünden gelen "status" kelimesidir. ${ }^{2}$

Devlet kavramının tanımlanabilmesi için mahiyetinin ne olduğunu bilmek gerekmektedir. Mahiyet tartışmalarını etkileyen faktörlerin en başında da, konuyu ele alan uzmanların kavrama bakış açıları gelmektedir. ${ }^{3}$ Bu konuda sosyolojik ve hukuki olmak üzere iki türlü bakış açısının olduğunu görüyoruz.

Sosyolojik bakış açısıyla bakan kimi uzmanlar ilkel bir kabile bile olsa eğer bir toplumda yöneten-yönetilen ayrışması meydana gelmişse ve yönetime karşı isyan kabul görmüyorsa orada adına "devlet" diyebileceğimiz bir yapı ortaya çıkmıştır. Bu ister bir reis veya seçilmişler tarafından yönetilen bir kabile olsun, isterse de bir kral veya parlamento tarafindan yönetilen bir devlet olsun aralarında mahiyet fark1 yoktur, sadece derece farkı vardır. Yani sonuçta ikisi de devlettir. ${ }^{4}$ Kavrama hukuki açıdan yak-

1 İbn Manzûr, Lisânu'l-Arab, (I-XV), 1. bs., Dâru Sadır, Beyrut, t.y., XI, 252.; er-Râzî, Muhammed b. Ebi Bekr b. Abdulkadir, Muhtaru's-Sıhah, thk. Muhammed Hâtır, Mektebetu Lübnan, Beyrut 1995, 218.; "Kelimenin Arapça'ya Akad dilindeki “amaçsızca dolaşmak” anlamına gelen "dâlu”dan veya Süryânice'de "hareket etmek, harekete geçirmek, canlandırmak ve yerini değiştirmek" anlamındaki "dâl” kelimesinden geçmiş olabileceği de ileri sürülmüştür.” Bkz. Ahmet Davutoğlu, “Devlet”, DİA, İstanbul, 1994, IX, 234.

2 Okandan, Amme Hukuku, 8.

3 Muhammed Kâmil Leyle, en-Nuzumu's-Siyasiyye ed-Devle ve'l-Hukûme, Dâru'n-Nahdati'l-Arabiyye, Beyrut, 1969, 24

4 Léon Duguit, Hukuk-i Esasiye, (Kaide-i Hukukiye-Devlet Meselesi), trc. Menemenlizade Edhem, Maarif 
laşanlara göre ise bu yeterli değildir. Eğer bir ülkede yaşayan toplumdan, egemenliği bulunan hükmi bir şahsiyetin ayrışması söz konusu ise o zaman bir devletten bahsedilebilir. ${ }^{5}$

Devlet örgütlenmesinin İslâm tarihi içinde ortaya çıkışı konusunda da gerek Müslüman düşünürler gerekse şarkiyatçılar tarafından faklı görüşler ileri sürülmüştür. Bu görüşler iki grup halinde değerlendirilebilir:

Birinci görüşü savunanlara göre Müslümanların devletleşmesi olgusu vahiyle başlamış ve Medine'ye hicretle birlikte hayata geçmiştir. ${ }^{6}$ Diğerlerine göre ise, Hz. Peygamber siyasî olmaktan çok dini bir liderlik oluşturmuştur ve onun döneminde bugünkü anlamda devlet örgütlenmesinden çok cemaat örgütlenmesi ön plana çıkmıştır. ${ }^{7}$ Birinci görüş devleti evrensel anlama sahip bir siyasi güç örgütlenmesi olarak ele alırken ikinci görüş devleti modern millet-devlet yapilanmasından hareket ederek yorumlamakta ve karşılaştırmayı bu esas üzerinden yapmaktadır.

Modern çağın teşkilatlı devlet yapılanmalarını temel almadan konuya yaklaşır ve devleti siyasi güç örgütlenmesi açısından ele alırsak, İslâm tarihinde devlet olușumunun miladi 620 ve 622 yillarında yapilan Akabe

Vekaleti Neşriyatı: 42, Matbaa-i Âmire, İstanbul, 1339, I, 299-301; Muhammed Faruk en-Nebehân, $N i$ zamu'l-Hukmi fi'l-İslam, Muessesetu'r-Risale, Beyrut 1988, 19.

5 Talip Türcan, Devletin Egemenlik Unsuru ve Egemenlikten Kaynaklanan Yetkileri, Ankara Okulu Yay., Ankara, 2001, 21.

6 Zeydân, Abdülkerim, 6.; Bâkır Şerif el-Kureşî, en-Nizâmu 's-Siyasî fi'l-İslam, 4.bs., Dâru't-Tearif, Lübnan, 1987, 131; Vahiyle birlikte başlayan devlet fikri genelde Müslüman düşünürlerde vardır. Müsteşrikler genelde Mekke döneminde böyle bir fikrin olmadığını söylerler ama Erich Pritsch bu konuda şöyle diyor:"Dini bir temel üzerine devletî oluşum Muhammed'in arkadaşlart ile birlikte kendi ana şehri olan Mekke'nin İlahlarına karşı açtığı savaşta kendini gösterdi. Daha sonra Muhammed'in Mekkeli taraftarları onunla miladın 622. yllında ileride Medine adını alan Yesrib'e göçtükleri zaman açıkça ortaya çıktı ve göç edenler, Yesriblilerle Muhammed'i Führer olarak tanıyan bir cemiyet kurdukları zaman merasimle teyit edildi." Bkz. Pritsch, 78.

7 Davutoğlu, IX, 235.; Mesela bu konuda A. Fuat Başgil şöyle diyor: “ Hulefa-i Raşidin devri sonlarına kadar İslam, esas itibariyle Arap kalmıs ve Arab'ın patriarcal (ataerkil) aile teşkilatını örnek almıştır. İslam 'in ilk devrinde cemiyet ve ihtiyaçlar basit olduğundan bu basit teşkilat yeterli gelmiştir. Emeviler zamanında 'İslami camia' hayli genişlemiş ve ilişkiler girift bir hal almıştır. İlk devirlerin basit ve patriarcal idare sistemi; dini bir teslimiyete istinat eden hukuki teşkilatı artık yetersizleşmiştir. Bu nedenle devlet merkezi Suriye gibi Roma'nın eski bir eyaletine nakledilmiş ve İslam burada Roma ve Bizans kültürleri ile karşılaşmıştır. Bu kültür karşılaşmasında İslam'ın hâkim kalabilmesi için kendi kültür ve teşkilatını kuvvetlendirmesi ve rakiplerinden geri kalmaması lazımdı. Bu lüzum önünde İslam, teşkilatını genişletmiş ve mürekkep ihtiyaçlı bir 'devlet' teşkilatı kurmaya çalışmıştır. Bunun için de Suriye'de Roma 'nın cumhuriyet devri teşkilatından kalma bazı usulleri İslamlaştırarak kendine mal etmişstir.” Bkz. Ali Fuat Başgil, Esas Teşkilat Hukuku, 55.

YIL: 6 SAYI: 11 
biatleri ile birlikte başlayan bir süreç içinde geliştiğinin tarihi bir gerçek olduğunu görürüz. ${ }^{8}$

\section{Geleneksel Arap Kabile Otoritesi.}

İslam öncesi Hicaz bölgesinde toplumsal yap1, göçebe yaşayanlar ve yerleşik hayata sahip olanlar olarak iki kısma ayrılmaktayd $1^{9}$ ve adına devlet diyebileceğimiz bir yapılanma söz konusu değildi. ${ }^{10} \mathrm{Bu}$ iki zümre arasında -Kureyş kabilesi gibi- yarı göçebeler ${ }^{11}$ olarak nitelendirebileceğimiz bir kesim de bulunsa bile hem çölde hem de şehirdeki yaşam şekline göçebe adetleri hâkimdi.

Yerleşik olanlar, Mekke, Medine ve Taif gibi şehirlerle, köylerde yaşayanlardı. Bunlar, geçimlerini tarım, hayvancılık ve ticaretle temin ediyorlardı. Göçebe olanlar ise çölde yaşıyorlar ve geçimlerini hayvancılıkla sağlıyorlardı. Ayrıca kervanların yolunu kesme ve yağmalama adetleri de vardi. ${ }^{12}$

İslam öncesi Arap toplum yapısının temeli, aynı babadan gelmiş olan fertlerin oluşturduğu kabilelerden meydana gelmekteydi. ${ }^{13}$ Kabileyi, aynı babadan gelenlerin yazılı olmayan örfi kurallar etrafında toplanması şeklinde tarif etmek mümkündür. ${ }^{14}$ Kabileler, çölün zorlu şartlarının şe-

Mehmed Niyazi, İslam Devlet Felsefesi, Ötüken Neşriyat, İstanbul, 1989; Davutoğlu, IX, 235.; Kimilerine göre Hz. Peygamber bir devlet fikrine sahipti ama devletin temelleri Hz. Ebu Bekir tarafından atılmış ve Hz. Ömer tarafindan da kurulmuştur. Bkz. A. Selçuk Özçelik, "İslam'da Devlet Müessesesinin İnkişafı”, IÜHFM, (XX/ 3-11), İstanbul, 1954, 7.; Faik Bercavî, İslam 'da Sosyalizm, Işık Basımevi, İstanbul, 1946, 28.

9 Cevad Ali, VII, 271

10 eș-Serif, 20.; Hasen, 29.

11 İbrahim Sarıçam, Emevi Hâşimî Iliş̧kileri, İslam Öncesinden Abbasilere Kadar, TDV Yay., Ankara, 1997, 22.

12 Cevad Ali, VII, 271.; İbn İbrî, Tarihu Muhtasari'd-Duvel, tsh. Anton Salhana el-Yesua, Dâru'r-Raidi Lübnaî, 2. bask1, Lübnan, 1994, 158.; Watt, Hz. Muhammed Mekke'de, 10.; Carl Brockelmann, İslam Milletleri ve Devletleri Tarihi, trc. Neşet Çağatay, AÜİFY., Ankara, 1954, 5.; Bernard Lewis, Ortadoğu, trc. Selen Y. Kölay, 3. bs..., Arkadaş Yayınevi, Ankara, 2006, 58.

13 K. Philip Hitti, History of The Arabs, 3. bs., Macmillan and Co. Limited, Londra, 1946, 23.; eş-Şerif, 29.

14 Cevad Ali, VII, 313.; Mahmud Mahmud Arafa, , el-Arabu Kable'l-İslam, Ayn li'd-Dirasât ve'l-Buhus li'l-İnsaniyye, ve'l-İctimaiyye, Kahire, 1995, 49.

"Kabile nizaminin esasl "asabiyet”tir. Bu da İslam öncesi Araplarında bir kimsenin "asabe"sini, yani baba tarafindan akrabalarını veya genelde kabilesini hakl veya haksiz olsun her meselede müdafaa etmeye hazır olmasi; kabile fertlerinin gerek kendi mal ve mülklerini korumak ve gerekse başkalarının mal ve mülklerini zapt etmek için birleşmesidir. Kabilede mümkün olabilecek nihai bağllllk unsuru bu asabiyettir. Kan akrabalı̆̆l, kabile yapısinda birleştirici rol oynamaktadır. 
killendirmiş olduğu toplumsal yapılard1. Bireyin mal ve can güvenliğini sağlayacak veya suçlulara karşı yaptırım uygulayacak herhangi bir tüzel yapılanma söz konusu olmadığı için bu tür ihtiyaçların kabile dayanışması ile giderilmesi mecburiyeti vard $1 .{ }^{15}$ Araplarda doğal bir ihtiyaç neticesinde ortaya çıkan bu kabilevî toplumsal yapı yerleşik hayata geçişin ardından da varlığını sürdürdü. Kadim gelenekler, kabile Arabının gerek günlük yaşamını ve gerekse kimliğini düzenlemeye hep devam etti. Dolayısıyla kabileler ve aşiretler İslam öncesi Arap otoritesinin en aşikâr sosyal ifadeleri oldular. ${ }^{16}$

Kabile içi dayanışma her zaman tek başına tehlikelere karşı bireyi veya kabileye mensup aileyi korumaya yetmiyordu. Çünkü zayıf birey ve aile olduğu gibi diğerlerine nazaran zayıf olan kabileler de oluyordu. $\mathrm{Bu}$ da onları bir üst şemsiye altında başka kabilelerle bir araya gelmeye mecbur ediyordu. $\mathrm{Bu}$ ittifaklar, Hilf ${ }^{17}$ (anlaşma-ittifak), velâ (koruma altına alma) ve civâr (sığınma) şeklinde cereyan ederdi. ${ }^{18}$

Asabiyet bağ ile kabileye mensubiyet kazanan fertler, kabile içinde son derece serbest düşünme ve hareket etme hürriyetine sahipken, kabile harici faaliyetler konusunda -ferdiyetçilik ortadan kalktığı için- özgürlüklerini yitirerek kabile ile özdeş kabul edilmekteydi. Kabilevî ilişkiler, bu kabilelerden herhangi bir bireye dokunulmaya engeldi. Çünkü bireyin

Nesep asabiyeti de denilen bu kabile dayanışması bağına göre herkes tehlike anında kardeşine yardımla mükellefti; hatta onun haklı veya haksız olduğunu sorma hakkına sahip değildi. Bu yükümlülük şüphesiz önce yalnız kendi boyuna düşerdi. Bunların gücü kafi gelmediği takdirde bütün kabile onun uğruna kendini ortaya atard.

"Zalim de olsa mazlum da olsa kardeşine yardımcı ol" sözü, kabiledaşa her durumda yardım öngörüldügünü göstermektedir. Kabile dayanışması nesep bakımından birbirine yakın olan kabileleri uzak olanlar aleyhine birleştirirdi." Bkz. Mahmud Arafa, 50; eş-Şerif, 30.

15 Watt, Hz. Muhammed Mekke'de, 23.

16 Hamid Dabaşi, İslam'da Otorite, trc. Süleyman E. Gündüz, İnsan Yayınları, İstanbul, 1995, 41.

17 “Anlaşma, ahitleşme, yeminleşme gibi anlamlara gelen 'hilf' kelimesi cahiliye döneminde kabile içi veya kabileler arasında her tülü konuda yardımlaşmay ifade etmektedir. Bu yardımlaşma başkalarına zulmetme üzerine dahi olabiliyordu. Yani burada amaç aslında güçlüye karşı korunmak iken ittifak edenler kötülük üzerine de anlaşabiliyorlardı. Bu şekildeki yardımlaşma şekli İslam 'la birlikte yasaklanmıştır." Bkz. Lisanu'l-Arab, IX, 53. Ayrıca bkz. Ebu'l-Hasen Ali b. İsmâil Seyyidi'l-Mursi, el-Muhkem ve'l-Muhît elA'zam, (I-XI), thk. Abdulhamid Hendavî, Dâru'l-Kutubi'l-İlmiyye, Beyrut, 2000, III, 346.; Zebidî, XXIII, 158.

18 eş-Şerif, 56, 62; Cevad Ali, VII, 356.; Câbirî, Arap-İslam Siyasal Akl, 2001, 99.; Mahmud Arafa, 54.; Watt, Hz. Muhammed Mekke'de, 24.

YIL: 6 SAYI: 11 
karşılaştığı herhangi bir kötülük ve eziyeti, kabile, bütünü için yapılmış sayardı. Kabilesi ile ters düşen, kabile iradesi dışında hareket eden üyenin üzerinden çöl güvenlik sisteminin adı olan "himaye" kaldırılmakta, soyuyla bütün bağı kesilmektedir ${ }^{19}$ ki, bu da bir Arabın karşılaşabileceği en büyük felakettir. Kabile, daima herhangi bir kabileyle veya öteki kabile gruplarıyla eski ya da yeni bir ittifak içindeydi ve yardım isteme hakkına sahipti. Nesep, hilf veya civar yoluyla mensup olduğu bir kabilesi bulunan herhangi bir bireye saldırı, kapsamlı bir iç savaş ateşini yakma tehdidiydi. ${ }^{20}$

Kabilenin siyasi teşkilatı ilkeldi. Kabile başkanı, eşit hak sahipleri arasından seçilen "seyyid" veya daha ziyade "şeyh" ${ }^{21}$ ad1 verilen kimseydi. Bu liderler kabile bireyleri tarafindan seçilirlerdi. Bu seçim kadim gelenekler çerçevesinde yapılmaktaydı; kabile reisliğine seçilecek olan kişinin, kabilenin diğer bireylerinden fazileti, cesareti, cömertliği, zenginliği, ileri görüşlülüğü, tecrübesi ve yaşı itibariyle temayüz etmesi gerekmekteydi. ${ }^{22}$

Aynı nüfuza sahip iki veya daha fazla şeyh adayı olursa yaşlı olan tercih edilirdi. ${ }^{23}$ Şeyhlik prensip itibariyle 1rsî değildi. Fakat onun evlatları kaabiliyet ve servetleriyle temayüz ederse başkanlık çok defa onun ailesinde kalmaktaydı. Şeyh kabile halkına yol göstermekten ziyade halkın iradesine uygun hareket ederdi. Onun idareciliği emretmekten çok hakemlik yapmaktı. ${ }^{24}$ Şeyh örfe uygun hareket etmek zorundayd1. Çünkü örf kanun yerine geçmekteydi. Örfün kuvveti atalara duyulan saygıdan ileri gelmekteydi. Şeyh harp zamanı hukuken komutan olurdu.

19 Hitti, 26-27.; "Birtakım bayağı kimseler vardı ki, bunlar, kabileye neye mal olacağını düşünmeksizin başlarını belaya sokmaktaydılar. Dolaylslyla kabileleri de kendilerine sahip çıkmazdı. Böyle bir kimse 'hali' diye taninirdl." Bkz. Watt, a.g.e., 25.

20 Câbirî, Arap-İslam Siyasal Akll, 103-104.; "İslam Öncesi Arap toplumunda kabile olgusu, toplumun tavır alım șeklinde önemli bir belirleyici unsur olarak kașımıza çıkmaktadır: 'Ben ve kardeşim, amcamın oğluna karşılyzz, ben ve amcamın oğlu yabancıya karşıyzz." Bkz. Cabiri, a.g.e., 99.

21 "SSeyh" kelimesi, olgun kişi ve aynı zamanda ihtiyar manasina gelmektedir. Bu kelimenin hem ihtiyar ve hem de kabile başkanina delalet etmesi, reislikte yaşa da önem verdiklerinden kaynaklanmaktadır. Bkz. Hitti, 28; "Ama yine de Araplar arasında büyük oğlun, babanin yerine geçmesiyle ilgili kesin hiçbir kural yoktu; bir reisin en büyük oğlu, babasının ölümü sirasında henüz tecrübesiz ise, kabile böyle bir kimseyi reis yapıp kendi varlı̆̆ın tehlikeye sokamazd. Reisin hikmet ve sağlam hüküm sahibi olmast gerekirdi." Bkz. Watt, a.g.e., 29.

22 eș-Şerif, 30; Mahmud Arafa, 50.

23 Corci Zeydan, IV, 45-46; V, 86.

24 Bernard Lewis, Tarihte Araplar, trc. Hakkı Dursun Yıldız, İstanbul, 1979, 27.; Hitti, 28. 
Hz. Muhammed'in doğduğu şehir olan Mekke'nin idaresi ve otoritesi seçkinler zümresinin tahakkümü altındayd $1^{25}$ ki bunlara, eşraf ve ileri gelenler anlamına gelen Mele' deniyordu. ${ }^{26}$ Mele', sadece Mekke'de değil aynı zamanda Taif, Medine, Necran ve Vâdi'l-Kurâ bölgesinin tümünde söz sahibi idi. ${ }^{27}$

\section{Hz. Muhammed ve Arap Kabile Otoritesine Karşı İlk Direniş.}

Hz. Muhammed, 571 yılında Mekke'de, Arapların zihninde "Fil Vakası" henüz tazeliğini koruyorken dünyaya gelmişti. ${ }^{28}$ Doğmuş olduğu Mekke şehri, tarihin en eski zamanlarından beri bilinegelen ve içerisinde Araplarca kutsal kabul edilen Kâbe'yi barındıran bir şehirdir.

\section{Hz. Muhammed'in de mensubu olduğu Kureyş kabilesi Arapların}

25 Ekrem Ziya Umerî, es-Sire en-Nebeviyye es-Sahiha, (I-II), Merkezu Buhûsi’s-Sunne ve's-Sîre, Katar, 1991, I, 80.

26 Mele': Reisler, toplumun önde gelenleri, bu şekilde isimlendirilmelerinin nedeni ihtiyaç duyulan şeyleri haiz bulunmalarındandır. Başka bir görüşe göre ise bir kavmin önderleri anlamına gelen "vücuh, ruesa, mukaddimûn" u ifade etmektedir ki bunların hepsi toplumda otorite olan ve sözleri dinlenen kişilerdir. Bkz. Lisanu'l-Arab, I, 159.

Kur'ân'a baktığımızda Mele' kavramı toplumda önde gelen tabakayı ifade etmekle beraber halkı yanlış yönlendirme ve Allah'a ibadetten alıkoyma gibi olumsuz tutuma sahip olan eşraf kastedilmiştir. Bu yönüyle daha çok olumsuz bir anlamı vardır.

Kur'ân, Hz. Nuh peygamberin kavmini uyarması ve doğru yolu tavsiye etmesine rağmen (Hûd, 25, 26) toplumun önde gelenlerinin (Mele'in) buna karşı çıktı̆̆ını ifade etmektedir. (Hûd, 27).

Âd kavmine gönderilen Hûd Peygambere de öncelikle karşı çıkanlar Mele' kavramı ile ifade edilmişlerdir. (A'raf, 66).

Semûd kavmine gönderilen Salih Peygambere karşı çıkan ve toplumu yönlendirenler de yine Mele'dir. (A'raf, 75,76).

Eyke'ye gönderilen ve ticarette hile yapmamaları için uyarılan kavmin de karşı çıkanları Mele'dir. (A'raf, 88)

Firavun'u Musa'ya karşı kışkırtan da Mele'dir. (A'raf, 127).

Hz. Muhammed, bedir gazvesinden dönen bir Ensarın "yaşlı, işe yaramaz birkaç kişi öldürdük" şeklindeki sözlerini işitince "onlar Kureyş’in meleiydi (önde gelenleri-kanaat önderleri)" demiştir. Bkz. İbn Hişâm, III, 193; Taberî, Tarih, II, 38.); yani başarılan iş büyüktür.

27 Cevad Ali, IX, 236.

28 İslâm öncesi dönemde Arapların, ünlü olaylarla bağlantılı olarak tarihlendirme yapma alışkanlıkları vardı. Örneğin Hz. Muhammed'in peygamberliğinden Medine'ye hicretine kadar geçen dönem için "Bi 'set" tarih olarak kullanılmış, önceki dönem için ise "Fil Olayı" tarih alınmıştır. Ancak Fil olayından şu kadar veya bu kadar gün sonra şeklindeki ilk çıkış noktasına ve çıkışta baz alınan gün ve ay durumuna göre Hz. Muhammed'in doğum tarihinin milâdî tarihle ifadelendirilmesinde farklı sonuçlar çıkarabilmektedir. Bkz. Hüseyin Algül, "Hz. Muhammed Devri Kronolojisi”, UÜIFD., (IV/4; 99-108.), Bursa, 1992, 101102; İbn Hişâm, es-Sire en-Nebeviye, (I-VI), thk. Taha Abdurrauf Sa'd, Dâru Cîl, Beyrut. 1411, I, 295; Muhammed Ebu Zehra, Son Peygamber Hz. Muhammed, (I-IV), trc. Mehmet Keskin, Kitabevi, İstanbul, 1993, I, 152-153: Mehmet Hüseyin Heykel, Hz. Muhammed Mustafa, trc. Ömer Riza Doğrul, Ahmed Halid Kitabevi, İstanbul, 1945, 38.

YIL: 6 SAYI: 11 
Adnânî veya İsmâilî olarak da adlandırılan koluna mensuptur. ${ }^{29}$ Bunlar Yemen'in kuzeyinde Tihâme, Hicâz ve Necd ile Suriye ve Irak'a kadar uzanan bölgede ikamet ediyor ve Hz. İsmâil'in soyundan sayıliyorlardı. ${ }^{30}$

Adnânîler devlet kuramamış olabilirler fakat göçebe karakterli bir toplum yapısına sahip olmaları onları başka devletlerin tahakkümünden de korumuş, böylece bütün kültürel hususiyetlerini yüzyıllar boyunca koruyarak nesilden nesile aktarabilmişlerdir. İslam öncesi Arap yarımadasının kültürel hususiyetlerinden bahsederken Philip Hitti şöyle söylemektedir:

“Arapları Arap yapan, özellikle de göçebeleri (önemli kılan) biyolojik, psikolojik, sosyal ve linguistik bakımdan Samioğullarının en önemli temsilcileri yapan nedenler, kendilerinin izole bir coğrafyada ve çöl hayatının monoton değişmezliğinde yaşamalarında aranmalıdır. Etnik saflık, tam da orta Arabistan'ın gerçekleştirebileceği gibi, en nahoş ve tecrit edilmiş çevrelerin kazandırabileceği bir ödüldür." ${ }^{31}$

İslam öncesi dönemde herhangi bir hükümdarın otoritesi altına girmemiş veya harâc cinsinden bir vergi vermiyor olma özelliği Araplar arasında kutsanmakta ve övünç vesilesi edinilmekteydi. Bu şekilde itaat altına alınmamış kavimler kendilerini "lekâh" (حاقَّ) şeklinde özel bir terimle vasıflandırıyorlardı. ${ }^{32}$ Hatta bu ifadeyi Hubel isimli putlarını selamlarken telbiye sirasında da söylerlerdi. ${ }^{33}$

Hz. Muhammed, oluşumunda herhangi bir dahlinin olmadığı, çerçevesini Arap kabilecilik geleneğinin çizmiş olduğu işte bu toplumsal yapı içerisinde doğup büyümüştü. İçinde yer aldığı toplumun kabile geleneklerine dayalı olan dinamiklerine -her ne kadar benimsemese bile- peygamberliği öncesinde kökten bir karşı çıkma tavrı içerisinde olmadığ 1 için çevresi tarafindan sayg1 görmekteydi. Ona duyulan saygı ve güven duygusu nedeniyle kendisine "el-Emîn" lakabı takılmıştı. ${ }^{34}$

29 Cevad Ali, I, 294-296.; Mahmud Arafa, 22.

30 Ebu'l-Fida, I, 99, 104.; İbn Haldûn, Tarih, II, 2, 33, 46.; Cevad, Ali, II, 26-28.; Corci Zeydan, 164.; Hasen, Ali İbrahim, 57-58.

31 Hitti, 8.

32 Lisanu'l-Arab, II, 579.; Cevad, Ali, IX, 303.

33 Cevad, Ali, XI, 252, 376.; "Müseylime de Peygamberlik iddiasında bulunurken kavmi Temimoğullarının 'lekâh' olduklarını ve boyun eğmeyeceklerini ifade eden, ayet olduğunu iddia ettiği sözler söylemiştir." Bkz. Taberî, Tarih, II, 276.

34 İbn Hişâm, I, 323.; İbn Sa'd, I, 121. 
Peygamberliğinin ilk evrelerinde, toplum içerisinde sahip olduğu olumlu imajın da etkisiyle Mekke'nin egemenlerinin çok sert bir tepkisiyle karşılaşmamıştı. Hz. Muhammed'in insanları gizlice İslam'a davet ettiği ilk üç yıl içerisinde Mekke egemenleri ilk şaşkınlığın etkisini atlattıktan sonra daha çok alaya alıcı ve refüze etmeye dönük bir tavır içerisinde olmuşlardı. Çünkü Hz. Muhammed'in peygamberlik iddiasını geçici bir heves veya delilik olarak görüyor ve zamanla işlerin yoluna gireceğini düşünüyorlardı.

Bir kısım Mekke ileri gelenleri de bu olayı kabileler arası rekabete yoruyorlar ve itirazlarını bu çerçevede dillendiriyorlardı:

Velîd b. Muğire, "Bizler iki büyük beldenin ulularl; Kureyş'in büyügü̈-efendisi ben ve Sakîf kabilesinin reisi Ebu Mesud Amr b. Umeyr dururken (bizler es geçiliyoruz da Kur'ân) Muhammed'e mi iniyor"35 diyerek Peygamberlik gibi önemli bir görevi güçlü ve zengin bir kabilenin seçkin liderlerinden birisinin ancak yürütebileceğini iddia ediyordu. Bu iddia, onların kutsiyet anlayışlarının da kabile merkezli olduğuna dair bazı ipuçlarını bize vermektedir: Velîd b. Muğire ve muadilleri (eşraf-mele') belki putperest inançlarından dolayı peygamberlik müessesine inanmıyorlardı. Belki de inanıyorlardı fakat kendi güç ve zenginliklerini de ilahi bir lütuf olarak algıladıkları için, Tanrılarının peygamber göndermek için bir seçim yapması durumunda muhakkak kendilerini tercih edeceklerini düşünüyorlardı. Ya da kabilenin zayıf bir sülalesinin üyesine Peygamberlik verilmesinden dolayı yaşadıkları hayal kırıklığını, inkâr yöntemiyle perdelemeye çalışıyorlard.

Asabiyet ve kabileler arası rekabet anlayışı kendilerini öylesine sarmıştı ki, Hz. Muhammed'in peygamberlik iddiası ile ortaya çıışıının ve bunun sonuçlarının neler olabileceği ile ilgili sağlıklı bir değerlendirme yapamıorlardı. Mekke'nin ileri gelenlerinden olan Ebû Cehil bile olayı kabileler arası rekabetin bir tezahürü olarak görüyor ve şöyle diyordu: "Biz (Mahzumoğulları) ve Abdümenafoğulları şan ve şeref konusunda birbirimizle yarlşttk durduk. Onlar yemek yedirdiler, biz de yedirdik. Onlar çeşitli görevler üstlendiler, biz de üstlendik. Onlar verdi, iyilik etti, biz de verdik, iyilik ettik. Develer üzerinde karşıllklı diz çöküp yarış atları gibi 35 ibn Hişâm, II, 207.

YIL: 6 SAYI: 11 
yarlştık durduk. Şimdi onlar gökten kendisine vahiy gelen bir Peygamberimiz var diyorlar. Biz buna nasll yetişebiliriz? Vallahi biz ona asla inanmayı ve onu tasdik etmeyiz." 36

Fakat peygamberliğinin dördüncü yılı başlarında Hz. Muhammed, Allah'ın emri ile insanları açıktan İslam'a davet etmeye ve müşriklerin putlarını kötülemeye başlayınca durum değişti. Mekke egemenleri neyle karşı karşıya olduklarını anladılar ve kendisine, dolayısıyla Müslümanlara karşı düşmanca tavırlar geliştirmeye başladılar. Bu konuda İbn İshak şöyle demektedir:

'Bana gelen haberlere göre Resûlullah (s.a.v.), kavmini İslam'a davete başlayınca ve Allah'ın emrettiği gibi tanrlarını anıncaya ve onlarl kınayıncaya kadar kavmi ondan uzaklaşmad, ona da gelmedi. Böyle yapınca (Tanrılarını kınayınca), olayın önemini kavradılar, hoşnutsuzluk gösterdiler ve ona karşı çıkmak ve düşmanlık konusunda fikir birliği oluşturdular." 37 İbn Sa'd da Zühri'den benzer bir rivayeti aktarmıştır. Zühri, Peygamberin üç yıl süreyle insanları gizlice davet ettiğini, daha sonra açıktan davetle emrolunduğunu belirttikten sonra şöyle diyor:

"Allah'ın davetine genç ve zaylf insanlardan bazıları karşılık verdi. Inananların sayısı çoğaldı. Kureyş kâfirleri söylediklerine aldırmıyordu. Meclislerine uğradığında kendisini göstererek 'Abdulmuttalipoğullarının çocuğu gökten konuşuyor' diyorlardı. Bu durum, Allah onların taptıklarl tanrılarını kınayıncaya ve kâfir olarak ölen atalarının mahvolduğunu belirtinceye kadar sürdü. İste o anda Resulullah'ı kavradılar ve ona düşmanca davranmaya başladılar." 38

Açık davetin başlaması ile beraber Mekkeli müşriklerin tanrılarının terk edilmesi gereken putlar olduğu, onlara inananların cehennemlik oldukları insanlara söylenmeye başladığında artık olay farklı bir boyuta taşınmış oluyordu. ${ }^{39}$ Çünkü ilk defa birisi Mekke'deki egemen din anlay1-

36 İbn Hişâm, II, 157, İbn Seyyidi'n-Nas, Uyunu 'l-Eser, (I-II), thk. Muhammed el-Îd el-Hatravî, Muhyiddin Müstû, Mektebetu Dari't-Turâs, Medine, 1992, I, 146.

37 İbn Hişâm, II, 98.; Taberî, Tarih, I, 543.

38 İbn Sa'd, I, 199.

39 Bayram Dalkılıç, "Hz. Muhammed'in Peygamberliği Aleyhinde İleri Sürülen Gerekçe ve İlkelerin Özellikleri Üzerine", Hz. Muhammed ve Evrensel Mesajı Sempozyumu, (277-297), Íslami Ilimler Dergisi Yay., Çorum, 2007, 280. 
şının dışında bir şeyler söylüyordu. Ayrıca, atalarını övünç kaynağı olarak gören bir topluma, onların sapıkça öldüklerinin, takip edilmemeleri ve örnek alınmamaları gereken kişiler olduklarının propagandasını yapıyordu.

$\mathrm{Bu}$ fikirler onları çok öfkelendirmişti ve bunda da kendilerince haklıydılar. Çünkü Hz. Muhammed, bütün toplumsal yapılarını ve inançlarını, atalarından devraldıkları örfî miras üzerine oturtan insanlara redd-i mirasta bulunmalarını ögütlüyordu. ${ }^{40} \mathrm{Bu}$ yüzden öfkeleri baskıya, baskılar da zamanla Müslümanlara karşı şiddete ve işkenceye doğru evrildi.

\section{Medine'ye Hicretin Zihinsel Arka Planı ve Akabe Bey'atları.}

Mekke'de açık davet sürecinde karşılaştıkları baskı ve işkenceler sonrası kendilerine bu topraklarda hayat hakkı tanınmak istenmediğini kavrayan Hz. Muhammed yeni bir çıkış yolu ve mü'minler için güvenli bir ortam arayışına girmişti. Bu amaca dönük olarak Mekke'de kurulan panayırlara gelen çevre kabile liderleri ile görüşmeler yapmakta idi. ${ }^{41} \mathrm{Bu}$ görüşmelerden birisi de Amir b. Sa'saaoğulları ile olmuştu.

Kendini Sa'saaoğullarına tanıtıp İslam'ı onlara anlattıktan sonra içlerinden Bayhara b. Firas ismindeki birisi "sana bu işte itaat etsek, ardından da sana karşı çıkanlara Allah seni üstün kılsa, senden sonra mülkü (yönetimi) bize birakır misın?" şeklinde bir soru yöneltti. Bunun üzerine Hz. Muhammed "iş Allah'ındır, onu dilediğine verir" diye cevapladı. Bu cevaptan memnun olmayan Sa'saaoğulları "senin için Arapları kendimize düşman mı edelim? Allah seni üstün kılarsa yönetim bizden başkasının olacak. Sana ihtiyacımız yok"42 diyerek daveti reddettiler.

Buradan da anlaşılacağı üzere Hz. Muhammed, inancın verdiği güçle Müslümanların Bizans ve Pers hükümdarlıklarını bile dize getireceğini

40 "Hz. Muhammed'in dile getirdiği mesaj yepyeni bir bakış açısı ve farklı bir değerler sistemi getiriyordu. Yerleşik sosyal ilişki biçiminin dışında bir ilişki biçimi öneriyordu. Dile getirilen mesaj dinsel ve ahlaki bir görünüme sahip olsa da, onun toplum içinde uygulanması sosyal davranışlarla ifade edileceği için, siyasi bir tepkiyle karşı karşıya kalmıştır. İktidar sahipleri Hz. Muhammed'in davetindeki siyasi özü fark etmekte gecikmediler. Onlar, geleneksel iktidar biçimlerinin zaafa uğrayacağını ve halkı yönetme güçlerinin ortadan kalkacağını anladılar." Bkz. Mehmet Evkuran, "Peygamber, Karizma ve Siyasal Otorite", İslami İlimler Dergisi. I/1, (51-67), b.y.y., 2006, 61.

41 İbn Hişâm, II, 270.; Taberî, Tarih, I, 555; İbn Kesir, el-Bidaye, III, 138.

42 İbn Hişâm, II, 272.; Taberî, a.g.e., I, 556.

YIL: 6 SAYI: 11 
düşünmekle beraber yapmak istediğinin bizatihi bu olmadığını bu tavrı ile ortaya koymuştur. Çünkü amacı sadece siyasi bir figür olarak tarih sahnesinde yerini almak değildir. Eğer öyle olsaydı bu amacı gerçekleştirmek için Sa'saaoğullarının akideyi dışarıda tutan ve sadece siyasi ittifak öneren tutumlarına olumlu karşılık verirdi. Dolayısıyla onun “Bizans ve Pers' $i$ hâkimiyet altına" alma fikri bir amaç değil inancın ulaşacağı tabii bir sonuç olarak şekillenmiştir.

Hz. Muhammed'in Mekke döneminde kafasında bir devlet kurma fikrinin olup olmadığı üzerinde çok fazla tartışmaya gerek yoktur. Mekke'de açık davetin başlaması ile birlikte Müslümanlara karşı, zaman ilerledikçe artan sistematik bir şiddet uygulanmakta idi. ${ }^{43} \mathrm{Bu}$ şiddeti uygulayanlar Mekke'nin, o zamanki siyasi gücü ellerinde bulunduran, egemen güçleriydi. Uygulanan baskı ve şiddet organize bir şekilde planlanıyor ve yürütülüyordu. Müslümanlar ise organize ve yaptırım gücüne sahip bir yapılanmadan mahrum durumdaydılar. Teşkilatlı bir mekanizmanın kendilerine uyguladığı şiddetten kurtulabilmek için aynı yapıya sahip olmak gerektiğini akli melekeleri yerinde olan her insan çok rahatlıkla kavrayabilir. Nitekim bu bilincin bir tezahürü olarak Hz. Muhammed Müslümanların bir kısmını Habeşistan’a göndermiştir. Onun bu tavrı, peygamberliğinin ana gayesinin her ne kadar devlet kurmak olmasa bile yine de tebliğin devamı ve hayatta kalabilmesi, güvenlik sorunun halledilebilmesi vb. gibi sebeplerle devletin gerekliliğine inandığının bir göstergesi olmuştur.

Hz. Muhammed, Mekke'deki ortamın Müslümanlar için İslam'ın bütün yönleri ile rahatlıkla yaşanmasına, teşkilatlanmasına uygun olmadığını gördükten sonra girdiği yeni arayışlar çerçevesinde yaptığ görüşmelerin hemen hepsinden olumsuz karş1lık alıyordu. Çünkü Sa’saaoğulları örneğinde olduğu gibi çevre kabileler, Kureyş kabilesi ile olan ilişsilerine zarar gelebileceği ve bu daveti kabul etmelerinin kendilerine güç ve servet anlamında bir şey kazandırmayacağı endişesiyle olumlu yaklaşım sergile-

43 Uygulanan baskı ve şiddetin sistematik olduğunun en büyük delili İbn İshak'ın rivayetindeki Ebu Cehil'in tutumudur. İbn İshak'ın rivayet ettiğine göre Ebu Cehil, güçlü ve zengin bir aileden gelen bir kimsenin Müslüman olduğunu duyunca, onu eleştirir ve ayıplardı. Onu, "senden daha iyi birisi olmasına rağmen sen babanın dinini terk ettin. Senin basiretini ahmakllk, muhakemeni temelsiz gibi gösterir, şerefini de alçaltırız" derdi. Eğer o, tüccar ise, "Allah'a yemin olsun ki mallarının satılmamasını ve iflas etmeni sağlayacağız" derdi. O kişi toplulukta etkisiz birisi ise, onu döver ve halkı da ona karşı kışkırtırdı. Bkz. İbn Hişâm, II, 162. 


\section{$212 \cdot$ YALOVA SOSYAL BILIMLER DERGISI}

miyorlard1.

Bu konudaki ilk olumlu tavır Yesribli (Medineli) Hazrec kabilesinden geldi ve on iki Medineli gizlice Hz. Muhammed'le Mekke'de, Akabe ${ }^{44}$ denilen yerde buluştu. "Birinci Akabe Bey'atı" 45 diye anılan buluşmada Medineliler, “Allah'a ortak koşmayacaklarına, çalmayacaklarına, zina etmeyeceklerine, çocuklarını öldürmeyeceklerine, birbirlerine iftirada bulunmayacaklarına, Resulullah 'ın emirlerine uyacaklarına" dair söz verip kendisine bey'at ettiler. ${ }^{46} \mathrm{~Hz}$. Muhammed de, Kur'ân'1, İslam'1 öğretmesi ve namaz kıldırması için Mus'ab b. Umeyr'i onlarla birlikte Medine'ye gönderdi. ${ }^{47}$

Mus'ab b. Umeyr'in hicret öncesi Medine'ye gönderilmesinin, psiko-sosyal açıdan bakıldığında stratejik bir karar niteliğinde olduğunu söylememiz mümkündür. Çünkü göç süreci hemen o yıl başlatılmış olsaydı bunun, büyük sıkıntıları beraberinde getirmesi kaçınılmazdı. Yeni gelenler her ne kadar Arap ve de benzer kültür yapısına sahip olan bireyler olsa da yeni inanç şeklinin onlara öğrettiği bir hayat tarzını benimsemiş olmaları onları farklı kılıyordu. Zaten Mekke'den ayrılmak zorunda kalmalarının ana sebebi de bu inanç farklılığ 1 idi. Ayrıca muhacirler aynı zamanda yeni yerleșimci demekti. Eğer yerleşik ahali onları içlerine alma konusunda

44 'Mekke'de Mescid-i Haram'a yaklaşık olarak 3 km. uzaklıkta ve Mina hudutları içerisindedir. Hac sırasında şeytan taşlanan Cemerât bölgesinde Cemre-i Akabe ismiyle anılan büyük şeytanın taşlandığg yere yakın etrafı tepelerle çevrili küçük kuytu bir vadidir. Günümüzde burada, Medineli Müslümanların Hz. Peygamber'e bey'at ettiğini hatırlatmak maksadıyla inşa edilmiş bir mescit bulunmaktadır.” Bkz. Önkal, Ahmet “Akabe Bey’atları”, DİA., İstanbul, 1989, II, 211.

45 “Bey’at Arapça bir kelime olup bir şeyi satmak anlamına gelen b-y-a (بيع (ب) fiilinin mastarıdır. Anlamı, teklif edilen bir sözleşmenin muhatabınca kabul edilmesidir. Siyasi literatürde ise, tarafların karşılıklı olarak birbirlerine belli ilkeler çerçevesinde söz vermeleri ve bu sözlerine sadık kalacaklarını beyan etmeleridir.” Bkz. Lisanu'l-Arab, VIII, 23; “Bey’at, Hz. Muhammed döneminde iyi günde, kötü günde zorlukta ve darlıkta onun yanında yer alacaklarına dair ashabın "işittik ve itaat ettik" şeklinde formüle ettikleri bir söz vermeydi. Erkekler ellerini Hz. Muhammed'in elleri üzerine koyuyorlar kadınlar da sözle ifade ederek bey'at ediyorlardı. Haccac b. Yusuf es-Sakafi (ö. 95/ 714) döneminden itibaren ise bey’at, talak, itâk, malın sadakası ve hac üzerine zorla yemin ettirmek gibi tasarruflarla desteklenir olmuştur. Talak ve itak'ın ikrah altında yapılması durumunda geçerliliği ile ilgili enteresan bir görüş de bu zorlamanın sultan tarafından yapılması halinde hükmün geçerli olması, bir hırsız tarafindan yapılması halinde ise geçersiz olmasıdır.” Bkz. el-Cevzî, İbnu'l-Kayyim, I'lamu'l-Muvakkiin an Rabbi'l-Alemin, (I-IV), tlk. Taha Abdurrauf Sa’d, Mektebe Külliyyati'l-Ezheriyye, Kahire, 1967, III/ 73-75; IV/ 35.

46 Taberî, Tarih, I, 558-559; İbn Sa'd, I, 220; “Bu bey’ate 'Kadınlar Bey'atı' ismi verilmiştir. Bu şekilde isimlendirilmesinin sebebi Hz. Muhammed'in gerekli olduğunda kendisiyle birlikte savaşmaları için onlardan bey'at almamıştır. Çünkü henüz savaşa izin veren ayetler nazil olmamıştı.” Bkz. İbn Hişâm, II, 279.

47 İbn Hişâm, II, 281; Taberî, a.g.e., I, 559

YIL: 6 SAYI: 11 
gerekli zihinsel hazırlığa sahip olmazsa yeni gelenleri işgalci olarak görebilirdi. Bu da temelleri atılmakta olan devletin sancılı ve hatta ölü doğmasına neden olabilirdi. Sonuç olarak atılan bu stratejik adım meyvelerini verdi ve Mus'ab'ın bir yıl içerisindeki faaliyetleri Medine ileri gelenlerinin Müslüman olmasını sağladı.

İlk bey'attan bir y1l sonra (m. 622) hac mevsiminde ikisi kadın 72 Medineli Müslüman, Mekke'ye geldi ve hacdan sonra yine Akabe'de Hz. Muhammed'le gizlice buluştu. Medinelilerin kendisini şehirlerine davet etmesi üzerine, Resulullah: "Hicret ettiği takdirde kendisini ve Mekkeli Müslümanları kendi canlarını, çocuklarını, kadınlarını ve mallarını koruduklart gibi koruyacaklarina, her şartta kendisine itaat edeceklerine, mali yardımda bulunacaklarına, iyiliği emredip kötülüğü önlemeye çallşacaklarına, kimseden çekinmeden hak üzere bulunacaklarına" dair söz vermelerini istedi. Medineliler de bu şartları kabul ettiler. ${ }^{48}$

Bunun üzerine Hz. Muhammed hicret kararını Ashabına iletti ve gruplar halinde gizlice Medine'ye geçişler başlad1. ${ }^{49}$ Mekke'de kalmaları durumunda kendilerini savunmada acziyet yaşamaları söz konusu olan bütün Müslümanlar güvenli bir şekilde hicret ettikten sonra $\mathrm{Hz}$. Muhammed de yakın arkadaşı Hz. Ebu Bekir'i yanına alarak Medine'ye hicret etti.

\section{Medine Site Devletinin Sosyal Alt Yapısı}

Hicret tamamlandıktan sonra artık Medine'de yeni bir süreç başlamış bulunuyordu; bu da yapılanma süreciydi. ${ }^{50} \mathrm{~Hz}$. Muhammed, bundan sonra dini liderliğinin yanında toplumu teşkilatlandırma görevini de üstlenen siyasi lider sıfatını da haiz bulunmaktaydı.

Mekke'nin yaklaşık olarak $440 \mathrm{~km}$. kuzeyinde yer alan Medine şehri (İslam öncesi adıyla Yesrib), İslam öncesi dönemde Hicaz bölgesinde yerleşik hayatın sürdüğü ikinci büyük şehir idi. Yesrib, verimli ve düz bir arazi üzerine kurulmuştur. Sulama yapmaya yetecek kadar su kaynakları

48 İbn Hişâm, II, 290-292; Taberî, a.g.e., I, 562; İbn Sa'd, I, 222; İbn Hanbel, Ahmed, Müsnedu Ahmed b. Hanbel, (I-VI), Müessesetu Kurtuba, Kahire, t.y., III, 322, 339, IV, 119- 120.

49 İbn Hişâm, II, 314.

50 Komisyon, ed-Devle el-İslamiyye, Vahdetu'l-Alakâti'l-Hâriciyye fi'l-İslam, el-Ma'had el-Âlemî li'l-Fikri'l-İslamî, 4. say1, Kahire, 1996, 157. 


\section{$214 \cdot$ YALOVA SOSYAL BILIMLER DERGISI}

bulunduğundan ziraata elverişlidir ve hurmalıklardan oluşan bir bitki örtüsü mevcuttur. Yesrib'in ilk sakinleri olarak Hz. Nuh'un soyundan gelen 'İbîl (veya Ubeyl) isminde birisinin ahfadından bahsedilmektedir. Daha sonra Amâlika kavmi buraya yerleşmiş ve burada hâkimiyet kurmuştur. ${ }^{51}$ Rivayetler Amâlika Kabilesinin içte salgın hastalık, dışta ise işgaller sonucu yıkıldıklarını göstermektedir. ${ }^{52}$

Hz. Muhammed'in hicret ettiği dönemde Medine toplumunun temelini oluşturan Arap ve Yahudi kavimlerinin buraya ne zaman yerleştikleri ile ilgili birçok rivayet bulunmaktadır..$^{53}$ Öncelik ve sonralık tartışmaları, özellikle Yahudiler açısından, kendilerinin Hicaz bölgesinin otokton halkı olduklarını ispat etmeleri yönüyle önem arz ettiğinden dolayı politik değer taşımaktadır. Bu yüzden kaynaklarda kimin önce yerleştiği ile ilgili çok farklı bilgiler mevcuttur.

Bir görüşe göre Babil baskınından kaçan Benî Kurayza, Benî Kaynukâ ve Benî Nadîr Yahudileri (m.ö. 587) Medine'yi yurt edindiler. ${ }^{54}$ Başka bir görüş ise, milattan sonra birinci asırda Roma'nın Suriye ve Mısır hâkimiyetinin ardından Şam'dan ayrılıp geldikleri şeklindedir. Roma'nın yaptığı zulüm, Yahudileri Roma hâkimiyetinden uzak bölge olan Arap Yarımadası'na göçe zorlamıştır (m.132-135). ${ }^{55}$

Araplar ise buraya Me'rib seddinin (barajının) yıkılması sonrasında (m.ö. 115-m.s. 275) yerleşmişlerdir. Arîm selinden sonra Yemen'den çıkmak zorunda kalan Ezd Kabilesi, Yesrib'e ulaştığında Hârise b. Sa'lebe, ailesi ile birlikte kabileden ayrılarak Yesrib'e yerleşmişti. Evs ve Hazrec ismindeki iki oğlundan gelecekte Ensar olarak anılacak olan Evs ve Hazrec Kabileleri ortaya çıktı. Evs ve Hazrec Kayleoğulları olarak da anılmaktadırlar. ${ }^{56}$

51 Taberî, Tarih, I, 128; İbn Haldûn, Tarih, II, 286; İbn Sa'd, I, 44; Dîneverî, Ahmed b. Davud, el-Ahbâru't-Tıvâl, Kahire, 1960, 3.; Corci Zeydan, 249; Cevâd, Ali, VII, 129.; İbn Neccar, Hafiz, ed-Durretu 's-Seniyye fi Tarihi 'l-Medine, thk ve tlk. Muhammed Azeb, Mektebe Sekafe Diniye, Port Said, t.y., 35.

52 Yaşar Çelikkol, "Cahiliye Döneminde Yesrib'in Etnik Yapısı”, FÜSBD., (XV/1, 319-346), Elazı̆̆, 2005, 324.

53 Abdulbasit Bedr, et-Târîhu'ş-Şamil li 'l-Medineti'l-Munevvere, (I-II), Medine, 1993, I, 14.

54 Taberî, Tarih, I, 317; İbn Haldûn, Tarih, II, 107; İbnu'1-Verdî, I, 28; İbn Neccar, 40-41.

55 Cevad Ali, XII, 94, 103, 114; İbn Haldûn, a.g.e, II, 190, 287.; "Bunların göç ederek Medine'ye yerleşen Yahudiler mi olduğu yoksa aslen Arap olup da sonradan mı Yahudileştikleri konusu da tam olarak netlik kazanmış değildir.” Bkz. Watt, Hz. Muhammed (Peygamber ve Devlet Kurucu), trc. Hayrullah Örs, Remzi Kitabevi, İstanbul, 1963, 91.

56 İbn Haldûn, a.g.e, II, 286, 287; Cevâd Ali, VI, 80, 81; VII, 129, 133, 136.

YIL: 6 SAYI: 11 
Rivayetlerden de anlaşıldığı üzere yerleşimcilerin buraya gelmesi ile ilgili rivayetler altı-yedi yüz yıllık bir zaman dilimini içermektedir ki bu kadar büyük bir zaman aralığında kimin önce kimin sonra geldiğini tam olarak ispatlayabilmek mümkün değildir. Fakat Mekke tarihi ile ilgili ve genel olarak Arap yarımadası ve özel olarak da Hicaz bölgesi ile ilgili olan tarihi kaynaklardaki bilgilerden yola çıkarak bazı çıkarımlarda bulunmamız mümkündür:

Medine'nin de içerisinde yer aldığ 1 Hicaz bölgesi, Kuzey ve Güney Arap Yarımadasına nisbeten daha izole bir bölgeydi. Daha önce de değindiğimiz gibi o dönemin süper güçleri Roma-Bizans ve Pers hükümdarlıkları buralara nüfuz edemiyorlard $1 .{ }^{57}$ Hatta bedevi Arapların sınır tecavüzlerinden korunmak için Romalılar Gassanileri, Persliler de Hirelileri kendilerine kalkan olarak kullanıyorlard1. Güneyde ise Yemen devletleri vardı ve bunlar da Ebrehe örneğinde olduğu gibi kuzeylerinde yer alan Hicaz bölgesini hiçbir zaman tam olarak hâkimiyet altına alamamışlardı.

Medine ayrıca Şam ticaret yolunun güzergâhı üzerinde yer alıyordu. Hicaz bölgesinde yaşayan Arapların kervanlar aracılığıyla Yemen ile Şam arasında ticaret yaptıkları, ayrıca diğer ülkelere ait malları taşıyan kervanlara da ücret mukabilinde eşlik ettikleri ve güvenliğini sağladıkları da tarihi bir gerçektir. ${ }^{58} \mathrm{Bu}$ da o bölgede bir Arap varlığını öncelemektedir. $\mathrm{Bu}$ nedenle büyük bir ihtimal Yahudi kavimleri buraya daha sonra yerleştiler ve zamanla da iktisadi üstünlügü ele geçirerek şehre hâkim oldular. Onların şehirdeki üstünlükleri yaklaşık olarak altıncı yüzyılın ortalarına kadar sürdü. Bu tarihten sonra üstünlük Arapların eline geçti; Yahudilerin, Evs ve Hazrec kabilelerinden herhangi birisiyle ittifak yapmadan tutunabilmeleri mümkün değildi. Bu ittifaklarda Yahudiler hep aşağı ortak durumunda bulunurlard1. ${ }^{59}$

Mekke, Medine'ye nazaran daha istikrarlı bir yapıya sahipti. Kâbe'nin varlığg onlara itibar kazandırıyor ve bunun yanında Kâbe hizmetlerinin yürütülmesi ile hacıların güvenliği meselesi de Kureyş için ortak bir amaç etrafında birleşebilmenin nirengi noktası oluyordu. Ayrıca ticaret kervanlarının güvenliği onların geleceğini garanti altına alacağı için istikrar ken-

57 Abdulbasit, 49.

58 eş-Şerîf, 241.

59 Watt, Hz. Muhammed (Peygamber ve Devlet Kurucu), 91. 


\section{$216 \cdot$ YALOVA SOSYAL BILIMLER DERGISI}

dini icbar ediyordu. ${ }^{60}$

Medine için ise aynı şeyler söz konusu değildi. Öncelikle kültürel bir homojenlik yoktu. ${ }^{61}$ Kâbe ve hizmetleri gibi kendilerine ortak bir gaye bahşedebilecek bir kutsal merkezleri yoktu. ${ }^{62}$ Çöldeki topluluk örgütlenmesi ilkeleri Yesrib'de aynıyla sürdürülüyordu. ${ }^{63}$ Üstelik kabile yaşayış1nın üstünlük elde etmeye dönük olan bütün unsurları onları rekabete ve çatışmaya sürüklüyordu. Bu çatışmadan nemalanan ve güç kazanan Yahudi unsurlar şehirdeki hâkimiyetlerini bu rekabet sayesinde pekiştirebiliyorlard1. ${ }^{64}$

Medine'de herkesin sözünü dinleyeceği veya yaptırım gücü olan, al1nan ortak bir karara uymak istemeyen kişi veya kabileye boyun eğdirebilecek merkezi bir otorite yoktu. Mekke'dekine benzer, asgari müştereklerde birleşmeyi temin edecek Dârunnedve benzeri bir yapılanma da mevcut değildi; tamamen kabile gelenekleri sosyal hayata hâkimdi. ${ }^{65}$

Müslümanların hicret ettiği dönemde Medine'deki yerleşim düzeni Kabile öbekleri şeklindeydi. Her kabile (Arap ve Yahudi) kendine ait bir mahallede otururdu ve kendine ait tarım arazileri mevcuttu. Kabileye mensup ailelerin oturdukları evleri ve her kabilenin "Utum" dedikleri muhkem, yüksek duvarlarla çevrili ufak kaleleri andıran binaları vardı. Kabile mensupları herhangi bir dış tehdit belirdiğinde bu "utum"lara sığınırlar ve kendilerini burada savunurlard1. ${ }^{66}$

Ağırlıklı olarak ziraatle uğraşmakla beraber Şam ticaret yolu üzerinde olmaları hasebiyle ticaretle de uğraşıyorlar ve tıpkı Mekkeliler gibi Şam’a kervanlarla gidip geliyorlard1. ${ }^{67}$

Yahudiler, Medine'nin merkezinde ve özellikle Şam yolu üzerinde yoğunlukla ikamet ediyorlard1. ${ }^{68}$

Evs kabilesi Medine'nin güneydoğusundaki nisbeten yüksek kesimleri oluşturan yerlerde ikamet ediyorlard1. Hz. Muhammed hicret ettiğinde

60 Watt, Hz. Muhammed Mekke'de, 151.

61 Watt, a.g.e, 151.

62 Eş-Şerîf, I, 263.

63 Watt, a.g.e, 151.

64 Abdulbasit, 70.

65 Hasen, Halid, Muctemeu'l-Medine Kable'l-Hicre ve Ba 'deha, Dâru'n-Nahda Arabiyye, Beyrut, 1986, 68.

66 Hasen, Halid, 26.; eş-Şerîf, I, 244.; Watt, Hz. Muhammed (Peygamber ve Devlet Kurucu), 93.

67 Hasen, Halid, 50.

68 eş-Şerîf, I, 245.

YIL: 6 SAYI: 11 
liderleri Sa'd b. Muaz'd1. ${ }^{69}$

Hazrecliler de Medine'nin orta bölgelerinde ve kuzey bölgesine doğru uzanan yerlerde ikamet ediyorlard1. Hz. Muhammed hicret ettiğinde liderleri Ebu Eyyub Halid b. Zeyd idi. ${ }^{70}$

$\mathrm{Bu}$ iki kabile uzun seneler boyu birbirleri ile savaşmışlardı. Hz. Muhammed hicret ettiğinde, iki kabile arasında uzun yıllar süren "Buas Savaş1” sona ereli de henüz beş sene olmuştu. ${ }^{71}$

İşte böyle bir sosyal tabana sahip olan Medine şehrinde oluşturulacak olan yeni yapılanmanın sağlam temellerinin olması stratejik öneme sahipti. Çünkü farklı ırklara ve dinlere ev sahipliği yapan Medine şehrinin, tarihinden de anlaşılacağı üzere kırılgan bir yapısı vardı. Eğer toplumu oluşturan farklı kesimleri bir araya getirecek ve onlara gaye birliği verecek ortak bir zemin oluşturulamazsa bu durum ilerde, özellikle Müslümanların Medine'deki varlıklarının kalıcılığı açısından, büyük bir tehlike arz edebilirdi. Hz. Muhammed teşkilatlı bir sosyal alt yapının İslam'ın tebliği açısından elzem olduğunun farkında olduğu için ilk icraatları bu yönde olmuştur. Bu nedenle teşkilatlanmanın ilk adımı olarak dini ve siyasi bir merkez niteliğini taşımakta olan Mescid-i Nebevi'nin inşaatına başlandı. Mescidin inşası yedi ay sürdü. Bu esnada Hz. Muhammed, Ebu Eyyub el-Ensari'nin evinde kaldı ve burada Medineli Müslüman erkeklerden, bir başka evde de kadınlardan bey'at aldı. ${ }^{72}$

Atılan her adımda bey'atın tekrarlanmış olması, bey'at uygulamasına kadınların da özellikle dâhil edilmesi, yeni oluşumun bütün aşamalarında toplumsal mutabakatın elde edilmesi, meşruiyetin sağlam temeller üzerinde yükselmesi için gerekli bir uygulamaydı. Burada bey'atı, körü körüne itaat değil de "toplumu oluşturan kesimlerin, belli ilkeler çerçevesinde ortak amaç için çalışma gayesi güdüleceğine dair kendi önderleri ile söz birliği etmesi” olarak algılamak daha doğru bir yaklaşım olacaktır. Çünkü Hz. Muhammed, kendisini dini ve siyasi bir lider olarak tanıan toplumundan kendi istek ve arzularına tabi olmasını değil tebliğcisi olduğu di-

69 Hasen, Halid, 29.

70 a.g.e.

71 a.g.e.

72 Ahmed b. Hanbel, Müsned, VI, 379, 408, 415; el-Heysemi, Nuruddin Ali b. Ebi Bekr, Mecmau'z-Zevaid, (I-X), Dâru'l-Fikr, Beyrut, 1412, VI, 37, 38 


\section{$218 \cdot$ YALOVA SOSYAL BILIMLER DERGISI}

nin ilkeleri çerçevesinde hareket etmelerini talep etmekteydi.

Teşkilatlanmakta olan yeni toplum Hz. Muhammed'in liderliği konusunda mutabakata vardıktan sonra sira Muhacirler ile Ensar arasinda ileride ortaya çıkabilecek ötekileşme ve beraberinde getireceği sıkıntıların ortadan kaldırılması için kaynaştırma uygulamasına gelmişti. Hz. Muhammed bu çerçevede Ensar ile Muhacirler arasında bir kardeşlik anlaşması vücuda getirdi. Rivayetlere göre, kardeşlik ilanı ve uygulaması Enes b. Malik' in evinde yapıldı. Resulullah, her Muhacirle bir Ensarı kardeş yapıyordu. ${ }^{73}$ Kardeşlik ilanına kırk beşi Ensardan kırk beşi de Muhacirlerden olmak üzere toplam doksan kişi katıldı. Sonunda Ensardan biriyle kardeş olmayan tek bir Muhacirin kalmadığı söylenmiştir. ${ }^{74}$

Bu kardeşlik akdi Muhacirlerle Ensar arasında maddi ve manevi yardımlaşmayı da beraberinde getiriyordu. Bir önemli özelliği de, bu kardeşler birbirlerinin akrabası olmadıkları halde birbirlerine mirasçı oluyorlardı. Kardeşler arasındaki bu ilişki, seviyeyi kan kardeşliğinin de üstüne çıkarıyordu. ${ }^{75} \mathrm{Bu}$ sayede "ümmet" ve "millet", kabilenin yerine geçmiş oluyordu. ${ }^{76}$

\section{Medine Site Devletinin Politik Alt Yapısı}

Hz. Muhammed, inananlarının hem dini hem de siyasi lideriydi ve bu çerçevede kendi toplumunun birlikteliğini yapmış olduğu uygulamalarla sağlamış bulunuyordu. Şimdi sıra aynı şehirde yaşamakta olan fakat inanç

73 İbn Sa'd, I, 238; el-Cevzî, İbn Kayyım, Zadu'l-Mead, thk. Şuayb el-Arnaût-Abdulkadir el-Arnaût, Muessesetu'r-Risale, Beyrut. 1986, III,56; İbn Seyyidi’n-Nas, I, 321; “İbn Hişâm, İbn İshak 'tan rivayetle bu kardeşlik ilanı sirasinda Hz. Peygamber 'in Hz. Ali'yi kendisi ile kardeş ilan ettiğini bildiriyor.” Bkz. İbn Hişâm, III, 36.

74 Belâzurî, Ensâbu'l-Eşrâf, thk, Süheyl Zekkâr, Riyaz Ziriklî, Dârul-Fikr, Lübnan, 1996, I, 319; İbn Sa'd, I, 238.

75 Buhari, Sahîhu'l-Buhari, (I-VI), thk. Mustafa Diyab el-Biğa, Dâru İbn Kesir, Beyrut, 1987, Fadailu's-Sahâbî, Büyu', 1, h.no: 1943, 1944; 2, h.no: 2170, 2171; Müslim, Sahihu Müslim, (I-V), thk. ve tlk. Muhammed Fuad Abdulbaki, Dâru İhya-i't-Turasi'l-Arabi, Beyrut, t.y., Fadailu's-Sahâbî, 50; İbn Sa'd, I, 238; İbn Kayyım, Zadu'l-Mead, III, 56; İbn Seyyidi'n-Nas, Uyunu'l-Eser, 1, 322

76 Câbirî, Arap-İslam Siyasal Aklı, 118.; "O zamana kadar toplumun bağı kan yakınlıkları idi, fakat bu, daha büyük topluluklar durumunda çok zayıftı -Evs ve Hazrec'in ortak atalardan gelmeleri aralartndaki şiddetli kavgaları önlememişti- ve topluluğa bağlllık, ferdiyetçilik yaygınlaş̧ıkça, davranışlar için yetersiz bir müeyyide oluyordu. Medine'de oluşturulan bu yeni topluluk birimi-ister akraba olsunlar isterse olmasinlar-peygamberin getirdiği ilkeler sayesinde bir araya gelebiliyordu." Bkz. Watt, Hz. Muhammed Mekke'de, 161.

YIL: 6 SAYI: 11 
yönüyle faklı bir kesimi oluşturan Yahudilerle sağlanacak mutabakata gelmişti. Çünkü Müslüman toplumun doğal olarak dini ve aynı zamanda siyasi lideri olan Hz. Muhammed'i Medineli yerleşik Yahudilerin ve diğer gayri-müslim unsurların en azından dini bir lider olarak görmedikleri aşikârd1.

Bu noktadan hareketle başta Yahudiler olmak üzere diğer inanç kesimlerini de kapsayacak bir siyasi bütünlüğün tesis edilmesi gerekmekteydi. Eğer bu gerçekleştirilmezse dini kardeşliğin tesisi ile oluşan toplumsal mutabakatın siyasi bir birliğe dönüşmesi ve bir devlet yapısının oluşturulabilmesi mümkün olmazdı. Bütün bu sakıncaların ortadan kaldırılması için Medineli Yahudilerin de katılımıyla şehirde yaşayan bütün kesimleri içerisine alan bir anlaşma yapıld. ${ }^{77}$ "Medine Vesikasl" adı verilen bu anlaşma ile Medine' de siyasi birlik sağlanmış, Hz. Muhammed bütün kesimlerce siyasi lider olarak tanınmış ve bir konsensüs elde edilmiş oluyordu. ${ }^{78}$

Bu vesikayı kısaca bir değerlendirmeye tabi tutarsak; devletin üç ana unsuru olan "Ülke", "Halk" ve "Siyasi Otorite" ile ilgili düzenlemeler getirdiğini görürüz:

77 İbn Hişâm, III, 31-35; İbn Kesir, el-Bidaye, 224-226; Hamidullah, Muhammed, Mecmûatu'l-Vesaik es-Siyasiyye li'l-Ahdi'n-Nebevî ve'l-Hilafeti 'r-Râşide, Dâru'n-Nefais, Beyrut, 1985, 59-62; ayrıntılı bilgi için bkz. Ekrem Ziya Umeri, Medine Toplumu, trc. Nureddin Yıldız, Risale Yay., İstanbul, 1988, 78-89.

78 "Konsensüs (Temel Anlaşma), genel anlamıyla, bir toplumda belli bir mesele üzerinde toplum üyelerinin büyük çoğunluğu arasinda görüş birliğini ifade eder. Temel anlaşmanin varliğından söz edebilmek için, toplum üyelerinin önemli bir kesimi (belki en azından \%75'i) arasında fikir birliği bulunması gerekir. Bir siyasal sistemin meşruluğu konusunda anlaşma (consensus) oranı ne derece yüksek olursa, rejim o derece kuvvetli bir temel üzerinde oturmuş demektir. Meşruluk göstergesinde (konusunda) anlaşma ibresi \%50 çizgisine doğru düştüğü zaman temel anlaşma da ortadan kalkar. Ancak burada iki ayrı hususu birbirine karıştırmamak lâzımdır. Toplumun bir kısım üyeleri (ki hayli geniş bir kitleyi kapsayabilir) belli bir zamanda siyasal iktidarı ellerinde bulunduran kişilere -veya partiye- karşı olabilirler. Fakat bu mutlaka onların siyasal sisteme karşı oldukları anlamına gelmez. İktidarı kullananların tutumlarına ve izledikleri politikaya karşı olmak başka şey, doğrudan doğruya iktidar tipine (siyasal sisteme) karşı olmak ve onun meşruluğuna inanmamak başka şeydir. Birinci halde, rejim içinde bir siyasal mücadele söz konusu olur; ikinci halde ise -Duverger'in deyimiyle- mücadele artık rejim üzerinde olmaktadır.

Toplumda, vatandaşların büyük çoğunluğu tarafindan paylaşılan bir meşruluk anlaylşl yerine, birden fazla meşruluk inancı arasında bir çatışma başladı̆̆ı zaman, temel anlaş̧mada bir çatışma, bir bölünme meydana gelmiş demektir. Bu çatlama, aslında toplumun sosyal yapısındaki bir çatlamayl-hiç değilse bir rahatsızlı̆̆ ve bunalımı- yansitır: Sosyal güçler dengesinde bir değişme olmuş, yeni güçler yeni isteklerle ve yeni ideoloji ile ortaya çıkmıştır. Yerleşmiş sistemin karşısına çıkan bu yeni hareket halk arasında kendisine geniş bir destek sağlayabildiği takdirde toplum ihtilâl ortamına girmiş sayllır. Rejim üzerindeki mücadele, baş̧ka deyişle meşruluk çatışması ve temel anlaşma yokluğu (dissensus) barış̧̧ıl yollardan giderilemeyecek olursa, sosyal gerilim sonunda ihtilâl veya iç savaşa kadar gidebilir.” Bkz. Kapani, 86-87. 
a. Bu belge ile kurulan devletin sınırları (Yesrib vadisinin içerisi, bu vesikaya bağll olanlara haram (dokunulmaz) bir bölgedir."- md. 39.) ortaya konmuş ve devletin ülkesinin Yesrib/ Medine olduğu tespit edilmiştir.

b. Belgede anlaşmanın tarafları olan bütün kabileler ve onların müttefikleri tek tek sayılmış ve yeni devletin halkının kimlerden meydana geldiği kayıt altına alınmış, onların diğer toplumlardan ayrı bir halk oldukları (Bu anlaşmanın taraflarl, diğer insanlardan ayr ve tek bir ümmet (cemaat) oluştururlar.- md. 2.) deklare edilmiştir. ${ }^{79}$

c. Kayıt altına alınan bir diğer husus da devletin siyasi otoritesinin kim (Üzerinde ihtilafa düştüğ̈̈nüz şey ne olursa olsun, iletileceği nihai merci; Allah'tır, Muhammed (s.a.v.)'dır. - md. 23/ Buradaki hükümlere uyan ve titizlik gösterenin (çiğnemekten kaçınanın) ilk hamisi Allah, sonra da Allah'ın elçisi Muhammed (s.a.v)'dir.'”- md. 47) olduğudur.

Ayrıca devletin idaresinde uyulacak hukuki kuralların neler olduğu da kayıt altına alınmıştır. Bunlardan bazılarını da şu şekilde özetleyebiliriz:

a. Bu vesika, anlaşmaya taraf olanların "inanç hürriyetlerini” (md. 25) garanti altına almaktadır.

b. Her grup kendi hisselerine düşen "kan diyetlerini" ve "savaş esirlerinin fidyesini” örfün belirlediği miktarlarda ödemekle yükümlüdür (md. $3,4,5,6,7,8,9,10,11)$.

c. Suç işleyenler hangi taraftan olurlarsa olsunlar asla himaye göremezler ve hukukun belirleyeceği cezai müeyyideler kendilerine uygulanır (md. 13, 21, 22, 25, 36, 46).

79 Medine sözleşmesi ile diğer insanlardan ayrı bir topluluk olarak kabul edilen Mü’minler, Müslümanlar ve Yahudiler ile onların anlaşmalısı olanlardan oluşan topluluğa "Siyasî Ümmet" de dememiz mümkündür. "Siyasî Ümmet", "Din Ümmetì" kavramından daha şümullüdür. Çünkü "Siyasî Ümmet", İnanan ve inanmayan, Müslim ve gayr-i Müslim insan topluluklarını ihtivâ etmektedir. Bu topluluğu birbirine bağlayan temel esas "iman" değil, bilakis "vatandaşlık" ilkesidir. Bkz. Mevlüt Koyuncu, "Medine Şehir Devleti", SÜFED., (2009-II), Sakarya, 2009, 96.

Sözleşmenin birinci maddesinde taraflar zikredilirken Muhacir ve Ensar'dan, Mü’minler ve Müslümanlar olarak bahsedilmiştir. Günümüzde bu ayırım çok fazla bir anlam ifade etmezken o dönem için bu önemli bir ayrımdı. Kur'ân da bu ayrımı yapmaktadır. Bedevilerden bazıları Hz. Muhammed'e gelip de "biz de inandık” demişlerdi. Fakat Kur'ân, onların henüz gerçek Mü’minler olmadıklarını beyanla, “....inanmadınız, ama Müslüman olduk deyin. Çünkü iman henüz kalplerinize sirayet etmedi” (Hucurat, 14) diyerek Müslümanlık ile Mü'minlik arasındaki bariz farkı ortaya koymuş oluyordu. Bu tanımlama, Medine'deki varlıklarından haberdar olunan Münafikların da anlaşmaya dahil olduklarının ve "Ümmet" grubu içerisinde değerlendirildiklerinin bir işareti olabilir. Bkz. Cabiri, Arap-İslam Siyasal Akl, 119.

YIL: 6 SAYI: 11 
d. Dış ilişkilerde taraflar anlaşma kurallarına riayet etmek kaydıyla yeni anlaşma ve ittifaklara gidebilirler (md. 17, 20, 45).

e. Taraflar düşmanın saldırısı söz konusu olursa ülke savunmasında işbirliği yapmakla sorumludurlar (md. 24, 37, 44).

Montgomery Watt, Medine Vesikası'nda Nadîr, Kurayza ve Kaynukaoğullarının zikredilmediğini, diğer Yahudi kabilelerinden de tali unsurlar olarak bahsedildiğini söyler. Ayrıca, Hz. Muhammed'in, sözleşmenin bütün taraflarınca otorite olarak tanınmasını, -bu tanınmayı sağlayan şeyin onun peygamberliği olduğunu iddia ederek- oluşturulan toplumun dini bir cemaat olduğu iddiasına gerekçe yapar. ${ }^{80}$

Halbuki tarihi gerçeklere ve "vesika" maddeleri olarak sunulanlara baktığımızda bu çıkarımın hatalı olduğunu söylememiz mümkündür:

Üç büyük Yahudi kabilesinin zikredilmemesi onların sözleşmeye dâhil edilmediği anlamına gelmez. Çünkü tarihi gerçeklerden biliyoruz ki Kaynukaoğulları, Hazrec ile; Nadîroğulları ve Kurayza, Evs ile anlaşmalı (ahlaf) idiler. ${ }^{81}$ Dolayısıyla sözleşmede açıç̧a zikredilen "Yesrib mü'minleri ve onların anlaşmalıları" cümlesi bu kabileleri de kapsamakta idi. ${ }^{82}$ Bilinen bir gerçektir ki zayıf olan bir kabile güçlü başka bir kabile ile anlaşmalı olunca bir nevi onun himayesine girmiş olurdu. Yani, zayıf olan kabile güçlünün bir nevi "mevlâsı" olurdu ki efendi zikredildikten sonra tabi olanın zikrine gerek yoktur. Bu ittifaklarda böyle bir güçlü-zayıf taraf ayrımı olduğunu ve Yahudi kabilelerinin de "zaylf taraf" olarak kabul edildiğini Watt'ın kendisi de söylemektedir. ${ }^{83}$

Ayrıca, sözleşmede Yahudileri işaret eden genel hükümlerin, onları da kapsamasından dolay1 ${ }^{84}$ buna ihtiyaç duyulmamış olabilir. Medine'de, Yahudiler denince ilk akla gelecek olan şey bu üç büyük kavimdir. Bunun yanında tarih kaynaklarında, onların da bu anlaşmanın tarafı oldukları

80 Watt, Hz. Muhammed, (Peygamber ve Devlet Kurucu), 100.

81 İbn Hişâm, III, 76.; Cevad, Ali, XII, 109.

82 "1. md. Bu, Allah' in Resulü Muhammed tarafindan Kureyş, Yesrib müminleri ve Müslümanlart ve bunlara tabi olanlarla, onlara sonradan katılanlar ve onlarla birlikte savas ve savunmayl taahhüt edenler arasında düzenlenmiş bir kitaptır (belgedir)."

83 Watt, a.g.e., 91, 104.

84 "16. md. Yahudilerden bize tabi olanlar, zulme uğramaksızın ve aleyhlerine bir mücadele kampanyası başlatılmaksızın yardım ve desteğimize hak kazanırlar."

"35. md. Yahudilere slğınmış ve bağlanmış olan kimseler, Yahudiler gibidir." 
farklı olayların anlatımı sırasında zikredilmektedir. ${ }^{85}$

Watt'1n tutarsız diğer bir iddiası ise sözleşmede, "diğer insanlardan ayrl ve tek bir ümmet (1. md)" olarak nitelenen yeni toplumsal yapının temelinin din olduğu iddiasıdır. Evet, bu topluma önderlik eden kişi peygamberdir, bir dini temsil ve tebliğ etmektedir. Tek tek bireyler veya sözleşmenin tarafları olan toplulukların tanımlanması açısından ele alındığında din eksenli bir değerlendirme olduğu ve buna göre safların belirlendiği de muhakkaktır. Ama sözleşmeyle bir araya getirilip "Ümmet" diye adlandırılan bu yeni devletin vatandaşlarının tabi oldukları yükümlülükler, tek bir dini veya dinleri esas almamaktadır; her topluluk, kendi içinde, inandığı dinin hukuku ile amel edecektir, ayrıca müşterek meselelerde de örfün belirlediği hükümler esas alınacaktır. Yani, çoğulcu bir hukuk sistemi (Legal Pluralism) öngörülmüştür. ${ }^{86}$

$\mathrm{Bu}$ açıdan bakıldığında Medine sözleşmesi, farklı dinlere mensup olsalar da, ortak ilkelere sadık kaldıkları müddetçe, başka din mensupları ile bir arada yaşama iradesinin beyanıdır. Bu sözleşmede amaçlanan şey, sadece Müslümanların birliği ve İslam'ın bütün kesimlere kabul ettirilmesi olsayd1, "Avfoğullarl Yahudileri, (bu konuda) müminlerle birlikte bir ümmet (bir topluluk) oluştururlar. Yahudilerin dinleri kendilerine, Müslümanların dinleri kendilerinedir, (bu hükme) hem kendileri hem de mevlâları dâhildir. (25. md)" ş̧eklindeki bir madde bu sözleşmeye yerleştirilmezdi.

Watt, Hz. Muhammed'in hiçbir zaman Medine toplumunun hükümdarı (hâkim siyasi otoritesi) olmadığını da söylemektedir. Ona göre yeni toplumsal sinıflar Arap kabile geleneğinden tamamen kopuk değildi ve sözleşmenin taraflarının hepsinin reisleri vard1. Hz. Muhammed de $\mathrm{Mu}-$ hacirlerin reisiydi. Üstelik sözleşmenin yirmi üçüncü maddesi (Üzerinde ihtilafa düşü̆günüz şey ne olursa olsun, iletileceği nihai merci; Allah 'tır, Muhammed (s.a.v)'dir.) onun hâkim değil de hakem olduğunu tescil et-

85 İbn Hişâm, III, 48, 314.; İbn Kesir, el-Bidaye, IV, 3-4, 75.; Taberî, Tarih, II, 48, 81.; eş-Şerîf, I, 333.

86 "Daha çok özel hukuk alanına giren konularla ilgili yapılacak bir düzenlemede veya bir davanın çözümünde, bireysel tercih ve kültürel farklllıkların bir sonucu olarak, farkl şekillerde düzenleme yapma veya hüküm verme imkânını sağlayan bir hukuk anlayışılır. Yine aralarında belirli düzeyde ilişski olan farkl hukuk düzenlerinin bir toplumda birlikte bulunması halinde de hukuki çoğulculuktan söz edilebilir." Bkz. Mehmet Salih Kumaş, Çok Hukuklu Sistem ve İslam Hukukundaki Yeri, Basılmamış Doktora Tezi, UÜSBE, Bursa, 2007, 122.

YIL: 6 SAYI: 11 
mekteydi. ${ }^{87}$

Hâlbuki vesikada ortaya konan ve kabilenin karşısına konumland1rılan "ümmet" kavramı, kabile ile türdeş veya özdeş bir kavram değildir. Ümmet içindeki ilişkiler, kabilede olduğu gibi nesebe değil, ortak ülkü ve yönelişe ve bir öndere dayanır. ${ }^{88}$ Dolayısıyla ümmet, kabileyi de içine alan ama onu reddetmeyen bir üst kimliktir; ümmete dâhil olanın kabilesini terk etmesine gerek yoktur. Bu yüzden, farklı kabilelere mensup olan Ensar'ın reislerinin mevcut olduğunu ve Hz. Muhammed'in onlar açısından siyasi bir otorite olmadığını söylerken, ümmetin diğer bir parçası olan ve farklı kabilelere mensup olan Mekkeli muhacirlerin tek bir kabile kabul edilip Hz. Muhammed'in onların reisleri olduğunun söylenmesi anlamsızdır.

Bütün bunlardan öte, sözleşmenin yirmi üçüncü maddesinde, $\mathrm{Hz}$. Muhammed'in, üzerinde anlaşmazlık olan konularda hakem olduğunun belirtilmesinin yanında, Watt'in görmezden geldiği bir başka maddede, onun otoritesine vurgu yapılmaktadır. Vesikanın kırk yedinci maddesi (Buradaki hükümlere uyan ve karşı gelmekten sakınanın ilk hamisi Allah, sonra da Allah'ın elçisi Muhammed'dir.) bu sözleşmedeki hükümlerin uygulanıp uygulanmadığının takipçisinin "Allah ve Rasulü” olduğunu belirtmektedir; yani yürütmenin başında Hz. Muhammed vardır ve sözleşmenin tarafları onu otorite olarak tanımışlardır. ${ }^{89}$ Netice olarak diyebiliriz ki, bu belgenin akdedilmesi ile birlikte siyasi birlik tesis edilmiş ve Hz. Muhammed'in siyasi otoritesi bütün taraflarca tescil edilmiş bulunuyordu.

Siyasi birlikten sonraki dönem içerisinde Medine'nin coğrafi sınırlar1nın tespiti çalışmalarının da Hz. Muhammed'in direktifleriyle yapıldığını kaynaklar zikretmektedir. ${ }^{90}$ Hz. Muhammed, Medine'nin sınırlarının belirlenmesi görevini Ebu Abdillah Ka’b b. Malik b. Ebî Ka’b Amr el-Hazreci’ye vermişti. ${ }^{91}$

Böylece modern çağın devlet yapısının temellerini de oluşturan ve devletin tanımsal olarak temel ögelerini içeren (Ülke, Halk, Siyasi Oto-

87 Watt, Hz. Muhammed (Peygamber ve Devlet Kurucu), 100, 101.

88 Cabiri, Arap-İslam Siyasal Akl, 123.

89 Lewis, Ortadoğu, 59.

90 Konu ile ilgili hadisler için bkz. es-Semhûdî, Ali b. Abdullah, Vefâu'l-Vefâ bi-Ahbari Dâri Mustafa, (I-V), thk: Kasım es-Samerrâî, Muessesetu'1-Furkân li't-Turâsi'l-İslam, Londra, 2001, I, 188-193

91 Hamidullah, Mecmûatu'l-Vesaik es-Siyasiyye, 64-65. 


\section{$224 \cdot$ YALOVA SOSYAL BILIMLER DERGISI}

rite) bir şekilde devlet oluşumu meydana gelmiş oluyordu. Çünkü nasıl adlandırırsak adlandıralım; bu, "Medine Şehir Devleti" veya "Medine Site Devleti" şeklinde olabilir, ülkesiyle, halkıyla, siyasi otoritesiyle yeni bir devlet teşekkül etmiş bulunuyordu.

\section{Sonuç}

Hz. Muhammed'in doğmuş olduğu Mekke şehri ve Hicaz bölgesi, Arap yarımadasının kuzey ve güneyinden birçok yönüyle farklılık arz etmekteydi. Öncelikle bu bölge, coğrafi olarak diğer yerlere nazaran daha izole bir yerdi. Güneyde bazı bağımsız devletler teşekkül etmişti, kuzeyde de Roma ve Perslere bağlı bazı vasal devletler mevcuttu. Fakat Hicaz'da Hz. Muhammed'in doğduğu zamana kadar, o bölgede yaşayan kabileler tarafından, ne bir devlet kurulabilmişti ne de burası herhangi bir devletin tam olarak egemenliği altına girmişti. İslam öncesi Hicaz bölgesi Arapları bu özelliklerine vurgu yapar ve bunu övünç meselesi kabul ederlerdi.

Mekke, Hicaz bölgesinin Medine ve Taif'le birlikte yerleşik hayatın mevcut olduğu üç şehrinden en önemlisi idi. Bu önemi, içerisinde barındırdığ1 ve bütün Arap kabilelerince kutsal kabul edilen Kâbe'den kaynaklanmakta idi. Bu üç şehirde yerleşik olan kabilelerin dışında kalanların hemen hemen tamamı göçebe bir hayat sürdürmekte idiler. Bunların çoğu hayvancılıkla uğraşırlar ve bazen de ticaret kervanlarına saldırarak çapulculuk yaparlardı. Şehirlerde yaşayanların (Medine'de nisbeten tarımsal faaliyetler ağırlıktaydı) ana geçim kaynağı ise ticaret yoluyla elde edilen gelirlerdi.

Hz. Muhammed, kabile esasına göre dizayn olmuş bir toplumsal yapı içerisinde dünyaya gelmişti. Zorlu çöl şartlarının icbar ettiği kabile yapılanması, nesebe dayalıydı ve kan bağı esasına göre örgütlenmişti. Bu bağ1 ayakta tutan ve devamını sağlayan şey ise kadim geleneklerdi. Tarihin bilinmeyen zamanlarından itibaren oluşmaya başlamış ve uygulanagelmiş olan kabile adetleri, Hicaz bölgesi Araplarının gerek günlük yaşamını ve gerekse kimliğini düzenlemeye hep devam etmişti. Bu sosyal yapı içerisinde bireyin tek başına bir anlamı yoktu; her yeni birey, kabile ve kadim gelenekler için taze kandan ibaretti. Hz. Muhammed'in doğduğu coğraf- 
yaya bu yönüyle tam bir sosyal ve kültürel homojenlik hâkimdi.

Israrlı kabile geleneklerinin hüküm sürdüğü bir ortamda yetişen $\mathrm{Hz}$. Muhammed, askeri ve ekonomik gücün, otoritenin temel kompozisyonunu belirlediği bir ortamda ilk vahiyleri insanlara tebliğ etmeye başladığında, muhatapları, tam olarak ne ile karşı karşıya olduklarını anlayamamakta, kendi kadim adet ve kültürleri içerisinde bu durumu nasıl bir çerçeveye oturtacaklarını tam olarak bilememekteydiler.

Mekke'dekiler, Hz. Muhammed'in getirmiş olduğu mesajın siyasi içeriğini fark etmede gecikmediler. Getirdiği mesaj, kadim kabile adetlerine meydan okuyor ve toplumu yeni bir evrensel düzen içerisinde (din kardeşliği çerçevesinde) yeniden örgütlüyordu. Bu türden bir meydan okuma Araplar için bir ilkti. Çünkü o zamana kadar hiç kimse onların dini, zihni, ahlaki ve sosyal davranışlarını yeniden düzenleme girişiminde bulunmamişt1.

Hz. Muhammed'in davetinin içeriğini kavrayan Mekke ileri gelenleri, bu hareketin kendi geleneksel otorite biçimlerini ve homojen toplumsal yapılarını değiştirme tehlikesini bertaraf etmek için Müslümanlara karşı dozajı sürekli artan sistematik şiddet uygulamaya başladılar. "Yeni Mü'minler Cemaati” kendilerine karşı düşmanca politikalar geliştirmekte olan bu organize güce karşı savunmasız bir haldeydi. Hz. Muhammed, kendisine ve inananlarına hayat hakkı tanınmak istemediğini görünce davetine olumlu cevap veren Evs ile Hazrec'in yurdu Medine'ye hicret etti.

Medine, Mü'minler için yeni bir başlangıç yapma adına büyük bir firsatt1. Müslümanların organize bir güç haline gelmesinin elzem olduğunun farkında olan Hz. Muhammed, Medine'nin siyasi birliğini sağlamak için bütün toplumsal kesimleri içine alan bir sözleşme akdetti. Medine Vesikas1 olarak bilinen bu sözleşme ile Hz. Muhammed, bütün taraflarca siyasi otorite olarak tanınmış oluyordu.

Böylece Müslümanlar, hicret sonrasında Medine'de bir site devleti kurmuş olarak tarih sahnesine çıkmış oluyorlard1. Çünkü, o günün şartlarıyla "Medine Site Devleti" bir devlet için gerekli olan asgari nitelikleri haizdi. Yani bu devletin bir Ülkesi (Medine), vatandaşları (Medine'deki Müslüman ve gayri Müslimler), Hz. Muhammed'in şahsında toplanmış 
226 - YALOVA SOSYAL BILIMLER DERGISI

ve anlaşmayla pekiştirilmiş Siyasi otorite ile yaptırım gücüne sahip bir düzeni (Egemenlik) vard1.

\section{KAYNAKÇA}

- Abdulbâsit, Bedr, et-Tarihu 'ş-Şâmil li'l-Medineti'l-Munevvere, (I-II), y.y., Medine, 1993.

- Akipek, Ömer, İlhan, Devletler Hukuku, y.y., Ankara, t.y.

— Algül, Hüseyin “Hz. Muhammed Devri Kronolojisi”, UÜIFD, (IV/4; 99108.), Bursa, 1992.

- Başgil, Ali Fuat, Esas Teşkilat Hukuku: Türkiye Siyasi Rejimi ve Anayasa Prensipleri, Baha Matbaas1, İstanbul, 1960.

- Belâzûrî, el-Buldan Futûhuhâ ve Ahkâmuhâ, thk. Suheyl Zekkar, Dâru'l-Fikr, Beyrut, 1992.

— ........., Ensâbu'l-Eşrâf, thk. Süheyl Zekkâr, Riyaz Ziriklî, Dârul-Fikr, Lübnan, 1996.

- ..........., Futuhu'l-Buldân, thk. Muhammet Ridvan, Lecnetu'l-Beyani'l-Arabî, Kahire, 1932.

- Besyunî, Abdulğanî Abdullah, Nazâriyyetu'd-Devle fi'l-İslam, ed-Dâru'l-Camiiyye, Beyrut 1986.

- Besyuni, Hasan es-Seyyid, ed-Devle ve Nizamu'l-Hukmi fi'l-İslâm, Alemu'l-Kütüb, Kahire, 1985.

- Bilsel, Cemil, Devletler Hukuku, İstanbul Üniversitesi Yay., Kenan Bas1mevi, İstanbul, 1941.

- Brockelmann, Carl, İslam Milletleri ve Devletleri Tarihi, trc. Neşet Çağatay, AÜİFY, Ankara, 1954.

- Buhari, Sahihu'l-Buhari, (I-VI), thk. Mustafa Diyab el-Biğa, Dâru İbn Kesir, Beyrut, 1987.

- Câbirî, Muhammed Âbid, Íslam'da Siyasal Akıl, trc. Vecdi Akyüz, Umut Matbaac1lık, İstanbul, 1997

- Celaluddin, Abdurrahman b. el-Kemal, ed-Durru'l-Mensûr, (I-VIII), Dâru'l-Fikr, Beyrut, 1993 
- Cevad, Ali, el-Mufassal fi Tarihi'l-Arab kable'l-İslam, (I-XX), 4. bs., Dâru's-Sâkî, b.y.y, 2001.

- Çağatay, Neşet, İslam'dan Önce Arap Tarihi ve Cahiliye Çăğ, AÜIFY., Mars T ve S.A.Ş. Matbaas1, Ankara, 1957.

- Çelikkol, Yaşar, “Cahiliye Döneminde Yesrib'in Etnik Yapısı”, FÜSBD, (XV/1, 319-346), Elazığ, 2005.

- Dabaşi, Hamid, İslam 'da Otorite, trc. Süleyman E. Gündüz, İnsan Yayınları, İstanbul, 1995

— Davutoğlu, Ahmet, "Devlet”, DİA., (IX/ 234-240), İstanbul, 1994.

- Duguit, Léon, Hukuk-i Esâsiye, (Kaide-i Hukukiye-Devlet Meselesi), trc. Menemenlizâde Edhem, Maarif Vekaleti Neşriyat1: 42, İstanbul, 1339.

- Ebu Zehra, Muhammed, Son Peygamber Hz. Muhammed, (I-IV), trc. Mehmet Keskin, Kitabevi, İstanbul, 1993.

- el-Cevzî, İbn Kayyım, Zâdu'l-Meâd, thk. Şuayb el-Arnaût, Abdulkadir el-Arnaût, Muessesetu'r-Risâle, Beyrut. 1986

- ..........., el-Muntazam fi Tarihi'l-Mulûk ve'l-Umem, (I-XIX) thk. Muhammed Abdulkadir Atta, Mustafa Abdulkadir Atta, Dâru Kütübi'l-İlmiyye, Beyrut, 1992.

- ........, I'lamu'l-Muvakkiin an Rabbi'l-Alemin, (I-IV), tlk. Taha Abdurrauf Sa'd, Mektebe Külliyyati'l-Ezheriyye, Kahire, 1967/1388

- el-Ezrakî, Ahbâru Mekke vema Câe mine'l-Âsâr, (I-II), thk. Ali Ömer, Mektebe es-Sekâfe ed-Diniyye, 1. bs., Kahire, 2003.

- el-Heysemî, Nuruddin Ali b. Ebi Bekr, Mecmau'z-Zevâid, (I-X), Dâru'l-Fikr, Beyrut, 1412.

- el-Himyerî, Muhammed b. Abdulmun'im, er-Ravdu'l-Muattar fi Haberi'l-Aktâr, thk. İhsan Abbas, Müessese Nasır li's-Sakâfe, 2. bs., Beyrut, 1980.

- el-Kureşî, Bâkır Şerif, en-Nizâmu's-Siyasî fi'l-íslam, 4.bs., Dâru't-Tearif, Lübnan, 1987.

- el-Vâî, Tevfik, ed-Devletu'l-İslamiyye beyne't-Turasi ve'l-Muasıra, Dâru İbn Hazm, Beyrut, 1996.

- en-Nebehân, Muhammed Faruk, Nizamu'l-Hukmi fi'l-İslam, Muessesetu'r-Risale, Beyrut 1988.

- er-Râzî, Muhammed b. Ebi Bekr b. Abdulkadir, Muhtaru's-Sihah, thk. 
$228 \cdot$ YALOVA SOSYAL BILIMLER DERGISI

Muhammed Hâtır, Mektebetu Lübnan, Beyrut, 1995.

- eş-Şerif, Ahmed İbrahim, Mekke ve'l-Medine fi'l-Cahiliyye ve Ahdi'r-Rasul, Dâru'l-Fikri'l-Arabi, Kahire, 1965.

- eş-Şeyh, Hüseyin, el-Arab Kable'l-İslam, Dâru'l-Ma'rife, İskenderiye, 1993.

- ez-Zebidî, Muhammed b. Muhammed b. Abdurrezzak, Tâcu'l-Arûs min Cevahiri'l-Kâmûs, (I-XL), thk. Komisyon, Dâru'l-Hidâye, t.y., b.y.y.

- Günaltay, M. Şemsettin, İslam Öncesi Arap Tarihi, Ankara Okulu Yay., Ankara, 2006.

- Güneş, Ahmet, "Medine Vesikasının İslam Hukuku Açısından Kaynak Değeri”, Ekev Akademi Dergisi, yı1:12, (XXXIV/ 211-222), b.y.y., Kış 2008.

- Hamidullah, Íslam Peygamberi, (I-II), trc. Salih Tuğ, İrfan Yayınevi, İstanbul, 1980.

— .........., "Hudeybiye Anlaşması", DİA, (XVIII/ 297-299), İstanbul, 1998.

- ..........., Mecmûatu'l-Vesâik es-Siyâsiyye li'l-Ahdi'n-Nebevî ve'l-Hilâfeti'r-Râş̧ide, Dâru'n-Nefais, Beyrut, 1985.

- Hasen, Ali İbrahim, et-Tarihu'l-İslamiyyi'l-Âm, Mektebe Nahda Misriyye, Kahire, t.y., 24.

- Hasen, Halid, Muctemeu'l-Medine Kable'l-Hicre ve Ba 'deha, Dâru'n-Nahda Arabiyye, Beyrut, 1986.

- Heykel, Mehmet Hüseyin, Hz. Muhammed Mustafa, trc. Ömer Riza Doğrul, Ahmed Halid Kitabevi, İstanbul, 1945.

- Hilmi, Mustafa, Nizamu'l-Hilafe fi'l-Fikri'l-íslamî, Dâru'd-Da've, 2. bs., İskenderiye, 2001.

- Hitti, K. Philip, History of The Arabs, 3. bs., Macmillan and Co. Limited, Londra, 1946.

- İbn Arabi, el-Avâsım mine'l-Kavâsım fî Tahkîki Mevâkıfi's-Sahâbe ba'de Vefâti'n-Nebiyyi, thk. Muhibüddin Hatîb, Dârü'l-Kütübi's-Selefiyye, Kahire, 1984

— İbn Haldun, Mukaddime, çev. Zakir Kadiri Ugan, Ankara 1997.

- ........, Tarihu İbn Haldûn, (I-VII), Muessesetu Cemal li't-tab' ve'n-Neşr, Beyrut, 1979.

YIL: 6 SAYI: 11 

., Tarihu İbn Haldûn: Kitabu'l-İber, (I-VII), Dâru'l-Kütübi'l-İlmiyye, Beyrut, 1992.

— İbn Hanbel, Ahmed, Müsnedu Ahmed b. Hanbel, (I-VI), Müessesetu Kurtuba, Kahire, t.y.

- İbn Hişâm, Sire Nebeviye, (I-VI), thk. Taha Abdurrauf Sa'd, Dâru Cîl, Beyrut. 1411.

- İbn İbrî, Tarihu Muhtasari'd-Duvel, tsh. Anton Salhana el-Yesua, Dâru'r-Raidi Lübnaî, 2. bask1, Lübnan, 1994.

- İbn Kesir, el-Bidaye ve'n-Nihaye, (I-XIV), Mektebetu'l-Mearif, Beyrut, t.y.

- .........., es-Siretu'n-Nebeviyye, (I-IV) thk. Mustafa Abdulvahid, Dâru'l-Ma'rife, Beyrut, 1971.

- İbn Manzûr, Lisanu'l-Arab, (I-XV), 1. bs., Dâru Sadır, Beyrut, t.y.

- İbn Neccâr, Hafiz, ed-Durretu's-Seniyye fi Tarihi'l-Medine, thk ve tlk. Muhammed Azeb, Mektebe Sekafe Diniye, Port Said, t.y.

- İbn Sa'd, Tabakât, (I-VIII), Dâru Sâdır, Beyrut, t.y.

- İbn Ziya, Ebu'l-Beka, Muhammed b. Ahmed, Tarihu Mekke el-Muşerrefe ve'l-Mescidi'l-Harâm ve'l-Medine eş-Şerife ve'l-Kabri'ş-Şerif, thk. Ala İbrahim, Eymen Nasr, Dâru Kütübi'l-İlmiyye, Beyrut, 2004.

- İbnu'l-Esîr, Ebusseadât el-Mubarek b. Muhammed el-Cezeri, en-Nihaye fi Garibi'l-Hadîs ve'l-Eser, (I-V), thk. Tahir Ahmed ez-Zavî, Mahmud Muhammed et-Tanahî, el-Mektebetu'l-İlmiyye, Beyrut, 1979.

- ........., el-Kâmil fi 't-Tarih, (I-IX), Halil Me'mun Şiha, Dâru'l-Ma'rife, Beyrut, 2002.

- .........., el-Kâmil fi't-Tarih, (I-X), thk. Ebi'l-Fida Abdullah el-Kâdî, Dâru'l-Kutub el-İlmiyye, 1. bask1, Beyrut, 1987.

- ........., Usdu'l-Ğâbe, (I-VII), thk. Adil Ahmed Rufai, 1. bs., Dâru İhyai't-Turas el Arabi, Lübnan, 1996.

— İbnu'l-Verdî, Tarihu İbni'l-Verdi, (I-II), Dâru Kütübi'l-İlmiyye, Beyrut, 1996.

- ............., Tetimmetu'l-Muhtasar fi Ahbari'l-Beşer (Tarihu İbni'l-Verdi), (I-II), thk. Ahmet Rifat el-Bedravi, Dâru'l-Ma'rife, Beyrut, 1970.

- Kapani, Münci, Poltika Bilimine Giriş, Bilgi Yayınevi, Ankara, 1997. 
- Karâfî, Ebu'l-Abbas Ahmed b. İdris, el-Furûk, (I-IV), thk. Halil el-Mansur, Dâru'l-Kütüb el-İlmiyye, Beyrut, 1998.

- Karaman, Hayreddin, Mukayeseli İslam Hukuku, (I-III), İz Yayıncılık, İstanbul, 2001

- Komisyon, ed-Devle el-islamiyye, Vahdetu'l-Alakâti'l-Hâriciyye fi'l-íslam, el-Ma'had el-Âlemî li'l-Fikri'l-İslamî, 4. sayı, Kahire, 1996

- Komisyon, el-Alakâtu'd-Duveliyye fi'l-Fikhi'l-İslam, Câmiatu'l-Ezher, Kahire, 1990.

— Koyuncu, Mevlüt, "Medine Şehir Devleti”, SÜFED., (2009-II/ 87-103), Sakarya, 2009.

- Kumaş, Mehmet Salih, Çok Hukuklu Sistem ve İslam Hukukundaki Yeri, Basılmamış Doktora Tezi, UÜSBE, Bursa, 2007.

- Lewis, Bernard Tarihte Araplar, trc. Hakk1 Dursun Yıldız, İstanbul, 1979.

- ......., Ortadoğu, trc. Selen Y. Kölay, 3. bs.., Arkadaş Yayınevi, Ankara, 2006.

- Leyle, Muhammed Kâmil, en-Nuzumu's-Siyasiyye ed-Devle ve'l-Hukûme, Dâru'n-Nahdati'l-Arabiyye, Beyrut, 1969.

- Mahmud, Mahmud Arafa, el-Arabu Kable'l-İslam, Ayn li'd-Dirasât ve'l-Buhus li'l-İnsaniyye, ve'l-İctimaiyye, Kahire, 1995.

- Malik b. Enes, Muvatta-Rivayetu Yahya el-Leysi, (I-II), thk. Muhammed Fuad Abdulbaki, Dâru İhyai't-Turasi el-Arabi, Misır, t.y.

- Manzuruddin, Ahmed, en-Nazariyyatu'l-İslamiyye fi'l-Asri'l-Hadîs, Arp. trc. Abdulmu'tî Emîn Kala'cî, Abdulcevad Halef, Camiatu'd-Dirasati' 'l-İslamiyye, Karaçi, 1988.

- Miftah, Ahmed Abdullah, Nizamu'l-Hukmi fi'l-İslam, Dâru't-Tevzi' ve'nNeşr el-İslamiye, Kahire, 2003.

- Müslim, Sahihu Müslim, (I-V), thk. ve tlk. Muhammed Fuad Abdulbaki, Dâru İhya-i't-Turasi'l-Arabi, Beyrut, t.y.

— Niyazi, Mehmed, İslam Devlet Felsefesi, Ötüken Neşriyat, İstanbul, 1989.

- Okandan, Recai G., Âmme Hukuku, İstanbul Üniversitesi Yay., İstanbul, 1952.

- Osman, Muhammed Fethi, Devletu'l-Fikre, Dâru'l-Kuveytiyye, Kuveyt, 1968.

- Önkal, Ahmet “Akabe Bey’atları”, DIA., (II/ 209-211), İstanbul, 1989.

YIL: 6 SAYI: 11 
— Özçelik, Selçuk, "İslam'da Devlet Müessesesinin İnkişafı", IÜHFM, (XX/3-11), İstanbul, 1954.

- Pritsch, Erich, "İslam'da Devlet Fikri", trc. Şakir Ansay, AÜSBFD, (I/1, 74-86), Ankara, 1943.

- Sarıçam, İbrahim, Emevi Hâş̧imî İlişkileri, İslam Öncesinden Abbasilere Kadar, TDVY, Ankara, 1997.

- Semhûdî, Ali b. Abdullah, Vefau'l-Vefa Biahbari Dari Mustafa, (I-V), thk: Kasım es-Samerrâî, Muessesetu'l-Furkân li't-Turâsi'l-İslam, Londra, 2001.

- Seyyidi'l-Mursi, Ebu'l-Hasen Ali b. İsmâil, el-Muhkem ve'l-Muhit elA'zam, (I-XI), thk. Abdulhamid Hendavî, Dâru'l-Kutubi'l-İlmiyye, Beyrut, 2000.

- Şevkâni, Muhammed b. Ali, Fethu'l-Kadîr el-Câmiu beyne Fenneyi'r-Rivâye ve'd-Dirâye min Ilmi 't-Tefsîr, (I-V), b.y.y., t.y.

- Taberani, Ebu Kasım Süleyman b. Ahmed, el-Mu'cemu'l-Evsat, (I-X), thk. Tarık b. Ivadullah b. Ahmed ve Abdulmuhsin b. İbrahim el-Hüseyni, Dâru'l-Harameyn, Kahire, 1415

- .........., el-Mu'cemu'l-Kebir, (I-XX), thk. Hamdi b. Abdulmecid es-Selefi, Mektebetu'l-Ulûm ve'l-Hikem, Musul, 1983.

- Taberi, Ahmed b. Abdullah, Zehairu'l-Ukba, Mektebet Kudsi, Kahire, 1356.

- Taberi, Muhammed b. Cerir, Camiu'l-Beyan an Te'vil'i Ayt'l-Kur'ân, (I-XII), b.y.y., t.y.

- Taberi, Tarihu't-Taberi -Tarihu'l-Umem ve'l-Muluk, (I-V), 1. bs., Dâru'l-Kutubi'l-İlmiyye, Beyrut 1407

- Taha, Hüseyin, el-Fitnetu'l-Kübra, (I-II), Dâru'l-Maarif, y.y., t.y.

- Tahavi, Abdulmelik b. Seleme Ebu Cafer, Şerh-u Meâni'l-Âsar, (I-IV), thk. Muhammed Zühri en-Neccar, 1. bs., Dâru Kütübi'l-İlmiyye, Beyrut, 1399.

- Tirmizi, Sunenu Tirmizi, thk. Ahmed Muhammed Şakir, Dâru İhyai't-Turasi'l-Arabi, Beyrut, t.y.

- Türcan, Talip, “İslam'da Dini Otorite”, SDÜIFD., (I/14, 95-123), Isparta, 2005.

- Türcan, Talip, Devletin Egemenlik Unsuru ve egemenlikten Kaynaklanan |YIL: 6 SAYI: 11 
232 - YALOVA SOSYAL BILIMLER DERGISI

Yetkileri, Ankara Okulu Yay., Ankara, 2001

- Umeri, Ekrem Ziya, Medine Toplumu, trc. Nureddin Yıldız, Risale Yay., İstanbul, 1988,

- Watt, W. Montgomery, Hz. Muhammed (Peygamber ve Devlet Kurucu), trc. Hayrullah Örs, Remzi Kitabevi, İstanbul, 1963.

- $\quad$..........., Hz. Muhammed Mekke'de, trc. M. Rami Ayas, Azmi Yüksel, AÜİFY., Ankara 1986.

- Zehebi, Siyer-i A'lami'n-Nübelâ, (I-XXIII), 9. bs., thk. Şuayb el-Arnaut, Hüseyin el-Esed, Muessesetu Risale, Beyrut, 1993.

- ........, Tarihu'l-İslam ve Vefayatu'l-Meşâhîri ve'l-E'lâm, (I-LII), thk. Ömer Abdusselam Tedmurî, Dâru'l-Kitâb el-Arabî, Beyrut, 1987.

- Zeydân, Abdülkerim, İslâm Hukukunda Fert ve Devlet, trc. Aksay Öncel, Nizam Yayınevi, İstanbul, t.y.

— ......., Corci, Kitâbu'l-Arabi Kable'l-İslam, 2. bs., Misır, 1922. 